\title{
The annual-cycle modulation of meridional asymmetry in ENSO's atmospheric response and its dependence on ENSO zonal structure
}

Article

Published Version

Zhang, W., Li, H., Jin, F. F., Stuecker, M. F., Turner, A. G. and Klingaman, N. P. (2015) The annual-cycle modulation of meridional asymmetry in ENSO's atmospheric response and its dependence on ENSO zonal structure. Journal of Climate, 28 (14). pp. 5795-5812. ISSN 1520-0442 doi: https://doi.org/10.1175/JCLI-D-14-00724.1 Available at https://centaur.reading.ac.uk/37885/

It is advisable to refer to the publisher's version if you intend to cite from the work. See Guidance on citing.

To link to this article DOI: http://dx.doi.org/10.1175/JCLI-D-14-00724.1

Publisher: American Meteorological Society

All outputs in CentAUR are protected by Intellectual Property Rights law, including copyright law. Copyright and IPR is retained by the creators or other copyright holders. Terms and conditions for use of this material are defined in the End User Agreement. 


\section{www.reading.ac.uk/centaur}

\section{CentAUR}

Central Archive at the University of Reading

Reading's research outputs online 


\title{
The Annual-Cycle Modulation of Meridional Asymmetry in ENSO's Atmospheric Response and Its Dependence on ENSO Zonal Structure
}

\author{
WENJUN ZHANG \\ Collaborative Innovation Center on Forecast and Evaluation of Meteorological Disasters, Key Laboratory of Meteorological \\ Disaster of Ministry of Education, Nanjing University of Information Science and Technology, Nanjing, and Key \\ Laboratory of Numerical Modeling for Atmospheric Sciences and Geophysical Fluid Dynamics, \\ Institute of Atmospheric Physics, Chinese Academy of Sciences, Beijing, China \\ HAIYAN LI \\ Collaborative Innovation Center on Forecast and Evaluation of Meteorological Disasters, Key Laboratory of Meteorological \\ Disaster of Ministry of Education, Nanjing University of Information Science and Technology, Nanjing, China \\ Fei-Fei Jin And Malte F. Stuecker \\ Department of Atmospheric Sciences, School of Ocean and Earth Science and Technology, University of Hawai'i at Mānoa, \\ Honolulu, Hawaii \\ ANDREW G. TURner AND Nicholas P. Klingaman \\ NCAS-Climate, Department of Meteorology, University of Reading, Reading, United Kingdom
}

(Manuscript received 20 October 2014, in final form 25 February 2015)

\begin{abstract}
Previous studies documented that a distinct southward shift of central Pacific low-level wind anomalies occurring during the ENSO decaying phase is caused by an interaction between the western Pacific annual cycle and El Niño-Southern Oscillation (ENSO) variability. The present study finds that the meridional movement of the central Pacific wind anomalies appears only during traditional eastern Pacific El Niño (EP El Niño) events rather than in central Pacific El Niño (CP El Niño) events in which sea surface temperature (SST) anomalies are confined to the central Pacific. The zonal structure of ENSO-related SST anomalies therefore has an important effect on meridional asymmetry in the associated atmospheric response and its modulation by the annual cycle. In contrast to EP El Niño events, the SST anomalies of CP El Niño events extend farther west toward the warm pool region with its climatological warm SSTs. In the warm pool region, relatively small SST anomalies are thus able to excite convection anomalies on both sides of the equator, even with a meridionally asymmetric SST background state. Therefore, almost meridionally symmetric precipitation and wind anomalies are observed over the central Pacific during the decaying phase of CP El Niño events. The SST anomaly pattern of La Niña events is similar to CP El Niño events with a reversed sign. Accordingly, no distinct southward displacement of the atmospheric response occurs over the central Pacific during the La Niña decaying phase. These results have important implications for ENSO climate impacts over East Asia, since the anomalous low-level anticyclone over the western North Pacific is an integral part of the annual cycle-modulated ENSO response.
\end{abstract}

\section{Introduction}

El Niño-Southern Oscillation (ENSO), the dominant coupled ocean-atmosphere climate phenomenon on

Corresponding author address: Dr. Wenjun Zhang, College of Atmospheric Sciences, Nanjing University of Information Science and Technology, 219 Ningliu Road, Nanjing 210044, China. E-mail: zhangwj@nuist.edu.cn interannual time scales, refers to an oscillation between warm (El Niño) and cold (La Niña) sea surface temperature (SST) conditions in the central-to-eastern equatorial Pacific and an associated zonal seesaw of atmospheric pressure anomalies between the west and east of the tropical Pacific basin. ENSO has received widespread public attention due to its strong impact on climate variability around the globe (e.g., van Loon and Madden 1981; Ropelewski and Halpert 1987, 1996; 
Trenberth and Caron 2000). In the second half of the twentieth century, great progress has been made in understanding the dynamical features of ENSO (e.g., Bjerknes 1969; Wyrtki 1975; Rasmusson and Carpenter 1982; Cane and Zebiak 1985; Neelin et al. 1998; Wallace et al. 1998). Tropical Pacific ocean-atmosphere interaction acts as the source to amplify initial SST and wind anomalies of ENSO (Bjerknes 1969). However, the Bjerknes positive feedback does not explain the phase change between ENSO warm and cold events. Various conceptual theories were proposed to explain the phase transition between El Niño and La Niña events through introducing a delayed negative feedback mechanism (e.g., Schopf and Suarez 1988; Battisti and Hirst 1989; Jin 1997; Picaut et al. 1997; Weisberg and Wang 1997). For example, the ENSO recharge oscillator theory highlights the importance of equatorial heat content discharge/recharge for ENSO's oscillatory behavior (Jin 1997). This mechanism has been substantiated by an empirical orthogonal function (EOF) analysis of the observed equatorial thermocline depth evolution (Meinen and McPhaden 2000).

In observations, ENSO exhibits a strong tendency to be phase-locked with the annual cycle (Rasmusson and Carpenter 1982; Stein et al. 2011, 2014). An ENSO event commonly starts evolving in boreal spring [March-May (MAM)] or summer [June-August (JJA)] and tends to reach its peak phase during boreal autumn [SeptemberNovember (SON)] or winter [December-February (DJF)]. El Niño (La Niña) events usually terminate in boreal spring (MAM) of the following year, accompanied by diminishing SST anomalies and a shoaling (deepening) thermocline in the eastern equatorial Pacific. This remarkable seasonal synchronization of ENSO with the annual cycle suggests a strong interaction between ENSO variability and the annual cycle itself. Previous theoretical studies based on nonlinear concepts have suggested a possible effect of the seasonal cycle on ENSO irregularity (Chang et al. 1994; Jin et al. 1994; Tziperman et al. 1994; Wang et al. 1999; Timmermann et al. 2003; An and Jin 2011). Several possible mechanisms were proposed for ENSO phase locking, such as a seasonal amplification of oceanic waves in the equatorial Pacific (Tziperman et al. 1998), or a negative feedback of the atmospheric response over the western North Pacific (WNP) (Guilyardi et al. 2003). At present, the underlying physical mechanisms by which ENSO events typically peak during boreal winter and terminate rapidly are not yet completely understood.

It has been suggested that the southward shift of the central Pacific zonal wind anomalies occurring in late winter or spring (Harrison 1987; Harrison and Larkin 1998) operates as a major contribution to the rapid El
Niño event termination during these seasons (Harrison and Vecchi 1999; Vecchi and Harrison 2003, 2006; Vecchi 2006; McGregor et al. 2012; Stuecker et al. 2013). This southward shift leads to a weakening of the westerly anomalies on the equator, thereby allowing the equatorial thermocline to adjust toward its normal state. This shift of anomalous low-level zonal winds to the Southern Hemisphere is mainly attributed to the southward displacement of the high background SST over the western and central Pacific and corresponding intensification of the South Pacific convergence zone (SPCZ) due to the seasonal evolution of solar insolation (Vecchi and Harrison 2003; Spencer 2004; Lengaigne et al. 2006; McGregor et al. 2012; Stuecker et al. 2013, 2015). The southward wind shift phenomenon is captured by the second EOF mode of the tropical Pacific surface wind anomalies, which is independent from the ENSO mode (captured by the first EOF) (McGregor et al. 2012, 2013; Stuecker et al. 2013). The second EOF mode results from the nonlinear interaction of the seasonal cycle and the ENSO-related SST variability based on analyses of the observed spectral characteristics and various modeling evidence (Stuecker et al. 2013, 2015). Accompanied by the southward displacement of the zonal wind anomalies in the second EOF mode is the development of the anomalous Philippine anticyclone during the El Niño decaying spring (Stuecker et al. 2013, 2015), which plays an important role by modulating precipitation over East Asia (Zhang et al. 2011, 2013b; Wang et al. 2013).

Additional, one of the latest major advances in ENSO research is the discovery of a new type of El Niño, which has occurred frequently over the central tropical Pacific in the recent two decades (Larkin and Harrison 2005; Ashok et al. 2007; Kao and Yu 2009; Kug et al. 2009; Yeh et al. 2009; Wang and Wang 2013; Zhang et al. 2014). This type of El Niño has its focus of ocean-atmosphere interaction over the central tropical Pacific. This is distinctly different from the traditional El Niño type, which has its maximum amplitude in the eastern tropical $\mathrm{Pa}$ cific. Various nomenclatures have been used to describe this type of El Niño, such as "date line El Niño" (Larkin and Harrison 2005), "El Niño Modoki" (Ashok et al. 2007), "warm pool El Niño" (Kug et al. 2009), and "central Pacific (CP) El Niño" (Kao and Yu 2009). However, the same phenomenon is investigated despite these different names and definitions. In this paper, the new type of El Niño is referred to as CP El Niño. Correspondingly, the term "eastern Pacific (EP) El Niño" is used to identify the traditional El Niño events. In contrast, it seems that no clear change in the zonal location of SST anomalies is detected for La Niña events (e.g., Kug et al. 2009; Kug and Ham 2011; Ren and Jin 2011), although this was challenged by 
some studies in terms of regional climate impacts (e.g., Cai and Cowan 2009; Zhang et al. 2015). In this study, all La Niña events are classified into one category, since almost all events show a similar evolution in the meridional movement of central Pacific wind anomalies.

Previous studies mentioned that the meridional displacement of wind anomalies plays a smaller role in the termination process of CP El Niño and La Niña events than that of EP El Niño events (Ohba and Ueda 2009; McGregor et al. 2012, 2013). These different features in the meridional movements of the zonal wind anomalies may contribute to the difference of ENSO persistence (Ohba and Ueda 2009; McGregor et al. 2013); for example, La Niña events persist much longer than EP El Niño events. Nevertheless, it was challenged by the study of Okumura and Deser (2010), in which the strong asymmetry in wind shifts between El Niño and La Niña is not found.

So far, a significant difference in the meridional movements of the atmospheric responses to different ENSO types (i.e., EP and CP El Niño, and La Niña) is still unclear. If the difference exists, what are the fundamental dynamics responsible for it? In this study, we will first investigate the coupled ocean-atmosphere features associated with the meridional movements of the central Pacific zonal wind anomalies for different types of ENSO. Furthermore, we will discuss possible physical mechanisms that explain the diversity in the wind anomaly migration for different ENSO types. The zonal structure of ENSO SST anomalies is emphasized as playing a major role in contrasting the nonlinear interaction of the annual cycle with different ENSO types. The rest of this paper is organized as follows: section 2 introduces data, methodology, and our definition of ENSO events. Section 3 illustrates different features of the zonal wind anomaly shift during various ENSO types. Section 4 examines inter-event variability associated with different ENSO types. In section 5, possible mechanisms are explored for the contrasting features of wind anomaly shifts during different ENSO types. The major conclusions and discussion are summarized in section 6 .

\section{Data and methodology}

\section{a. Data}

In this study, the tropical Pacific domain $\left(30^{\circ} \mathrm{S}-30^{\circ} \mathrm{N}\right.$, $100^{\circ} \mathrm{E}-80^{\circ} \mathrm{W}$ ) is our focus. To examine the southward wind shifts, we utilize monthly 10-m wind data (1979-2013) from the European Centre for Medium-Range Weather Forecasts (ECMWF) interim reanalysis (ERA-Interim; Dee et al. 2011). ERA-Interim is the latest ECMWF global atmospheric product at approximately $0.7^{\circ}$ horizontal resolution. The post-1979 period is available because of the improved satellite data since then. Other wind productssuch as the 40-yr ECMWF Re-Analysis (ERA-40; Uppala et al. 2005) over 1958-2001 and the National Centers for Environmental Prediction-National Center for Atmospheric Research reanalysis (Kalnay et al. 1996) over 1950-2013 - have also been analyzed and they show no qualitatively different results. This similarity in different products has also been mentioned by McGregor et al. (2013). The SST anomalies (1979-2013) associated with different types of ENSO were examined based on the global sea ice and sea surface temperature analyses from the Hadley Centre (HadISST1) provided by the Met Office (Rayner et al. 2003). Correspondingly, ENSO-related convection anomalies are investigated by using the Global Precipitation Climatology Project (GPCP) monthly precipitation dataset (Adler et al. 2003) from 1979 to 2013. The spatial resolution of the SST and precipitation datasets is $1^{\circ} \times 1^{\circ}$ and $2.5^{\circ} \times 2.5^{\circ}$, respectively.

Anomalies for all variables were calculated as the deviation from the 30 -yr climatological mean over the period 1981-2010. To focus on the time series associated with ENSO (both interannual and near-annual variability) (Stuecker et al. 2013), a 6-120-month bandpass filter is applied to each dataset using the second-order Butterworth filter designed by Parks and Burrus (1987). The nonfiltered data were analyzed as well, with no qualitative impact on the results. Linear regression and composite analysis methods were used to analyze the meridional movements of the tropical Pacific Oceanatmosphere system. All statistical significance tests were performed using the two-tailed Student's $t$ test. The ENSOrelated composites are arranged by calendar months.

\section{b. Definition of ENSO events}

The Climate Prediction Center (CPC) defines ENSO warm and cold events based on a threshold of $\pm 0.5^{\circ} \mathrm{C}$ for a 3-month running mean of Niño-3.4 $\left(5^{\circ} \mathrm{S}-5^{\circ} \mathrm{N}, 120^{\circ}-\right.$ $\left.170^{\circ} \mathrm{W}\right)$ SST anomalies. Use of the CPC definition identifies nine El Niño events (1982/83, 1986/87, 1991/92, 1994/95, 1997/98, 2002/03, 2004/05, 2006/07, 2009/10) and seven La Niña events (1983/84, 1988/89, 1995/96, 1998/ 99, 2005/06, 2007/08, 2010/11) over the period 19792013. The ENSO years listed here correspond to Year(0)/ Year(1), where 0 and 1 refer to the ENSO developing and decaying year, respectively. A typical El Niño event tends to develop during the spring or summer season and usually lasts for about one year. However, an exceptional long-lasting El Niño event occurred in the late summer of 1986 and prevailed until early 1988, with two peak winter seasons. Results from previous studies indicated that the 1986-88 El Niño consists of SST anomaly spatial structures of both EP and CP El Niño (e.g., Ashok et al. 2007; Kug et al. 2009; McPhaden et al. 2011). Because of this 


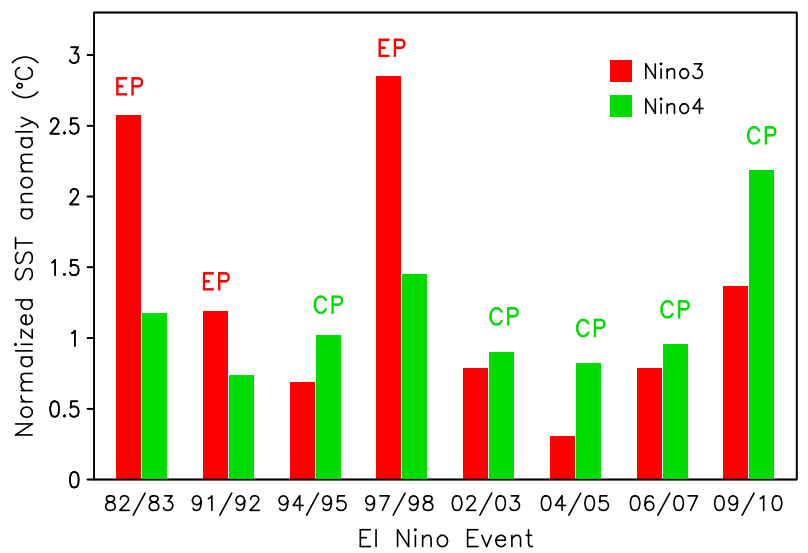

FIG. 1. Normalized Niño-3 (red) and Niño-4 (green) SST anomalies $\left({ }^{\circ} \mathrm{C}\right)$ during El Niño winter seasons (DJF) after the early 1980s. EP and CP indicate different types of the El Niño events as described in the text.

ambiguity, we exclude this specific event from our following analysis. We identify three EP El Niño events (1982/83, 1991/92, 1997/98) and five CP El Niño events (1994/95, 2002/03, 2004/05, 2006/07, 2009/10) based on the normalized Niño-3 (SST anomaly averaged over the region $5^{\circ} \mathrm{S}-5^{\circ} \mathrm{N}, 90^{\circ}-150^{\circ} \mathrm{W}$ ) and Niño-4 (SST anomaly averaged over the region $5^{\circ} \mathrm{S}-5^{\circ} \mathrm{N}, 160^{\circ} \mathrm{E}-150^{\circ} \mathrm{W}$ ) indices that have usually been used to define the two different types of El Niño (e.g., Kim et al. 2009; McPhaden et al. 2011; Ren and Jin 2011). The El Niño events with Niño-3 warming greater than Niño-4 warming during the winter season are defined as EP El Niño, and those with Niño-3 warming less than Niño-4 warming during the winter season are considered as CP El Niño (Fig. 1). These two types of El Niño events selected are the same as those defined by McPhaden et al. (2011), except for the 1986-88 El Niño event. Some controversy exists in discerning the type of the 1991/92 El Niño event. Some studies defined it as EP El Niño (e.g., Larkin and Harrison 2005; Yeh et al. 2009; McPhaden et al. 2011; Cai et al. 2012) whereas other studies classified it as CP El Niño (e.g., Ashok et al. 2007; Kao and Yu 2009; Kim et al. 2009). In this study, the 1991/92 El Niño event displays a feature similar to the EP rather than the $\mathrm{CP}$ type. Hence, this El Niño event is classified into the EP type. The main conclusion is not affected even if this $\mathrm{El}$ Niño event is excluded.

La Niña events usually have a longer duration than El Niño events. Many La Niña events persist through their second year and sometimes reemerge in the subsequent winter (e.g., Ohba and Ueda 2009; Ohba et al. 2010; DiNezio and Deser 2014; Hu et al. 2014). For example, the 1998/99 La Niña event starts at about July 1998 and lasts for nearly three consequent years. In this paper, the peak during the first winter is our focus to analyze the associated meridional movements in the zonal wind. Hence, the La Niña composites are calculated by treating the first winter season as the mature phase. Note that the main conclusions regarding La Niña events are not affected by the choice with or without the long-lasting events.

\section{Contrasting features in meridional shifts of zonal wind anomalies for different ENSO flavors}

An EOF analysis was applied to the monthly surface wind anomalies over the equatorial Pacific $\left(10^{\circ} \mathrm{S}-10^{\circ} \mathrm{N}\right.$, $100^{\circ} \mathrm{E}-80^{\circ} \mathrm{W}$ ) to extract the spatial and temporal features of the wind variability. The leading two EOF modes account for $40.1 \%$ and $21.4 \%$ of the total variance, respectively. The EOF spatial patterns are obtained by a regression of the observed wind anomalies on the normalized principal component (PC) time series associated with the leading two EOF modes (Figs. 2a,b). The leading EOF pattern (EOF1) captures the well-known wind anomaly pattern associated with El Niño, characterized by the equatorially quasisymmetric westerly wind anomalies over the central Pacific and convergence onto the equator in the east (Figs. 2a and 3), consistent with the reduced equatorial upwelling. The corresponding PC time series (PC1) is highly correlated $(R=0.95)$ with the time series of the Niño-3.4 index (SST anomalies averaged over the Niño-3.4 region) (Fig. 2c), suggesting that PC1 captures the main ENSO mode. Because of the high consistency of the Niño-3.4 index and PC1, we will use the Niño-3.4 index instead of PC1 in the remainder of the paper.

In the second EOF (EOF2), the pattern is highly antisymmetric about the equator (McGregor et al. 2012; Stuecker et al. 2013). This structure is characterized by easterly anomalies north of the equator and westerly anomalies south of the equator (Fig. 3). The westerly anomalies south of the equator in the central Pacific correspond to the southward displacement of zonal wind anomalies during the El Niño decaying spring season as mentioned by earlier studies (Harrison 1987; Harrison and Larkin 1998). This dominant wind anomaly pattern has been referred to as a combination mode (C-mode), produced by the interaction between ENSO and the annual cycle (Stuecker et al. 2013). A strong low-level anticyclonic circulation anomaly over the western North Pacific (WNP) accompanies the southward shift of central Pacific wind anomalies (Fig. 2b). The combination of EOF2 and its corresponding PC2 shows that the strong C-mode pattern emerges rapidly several months after the EP El Niño peak. Interestingly, a weak C-mode wind anomaly pattern is detected when CP El Niño (and 

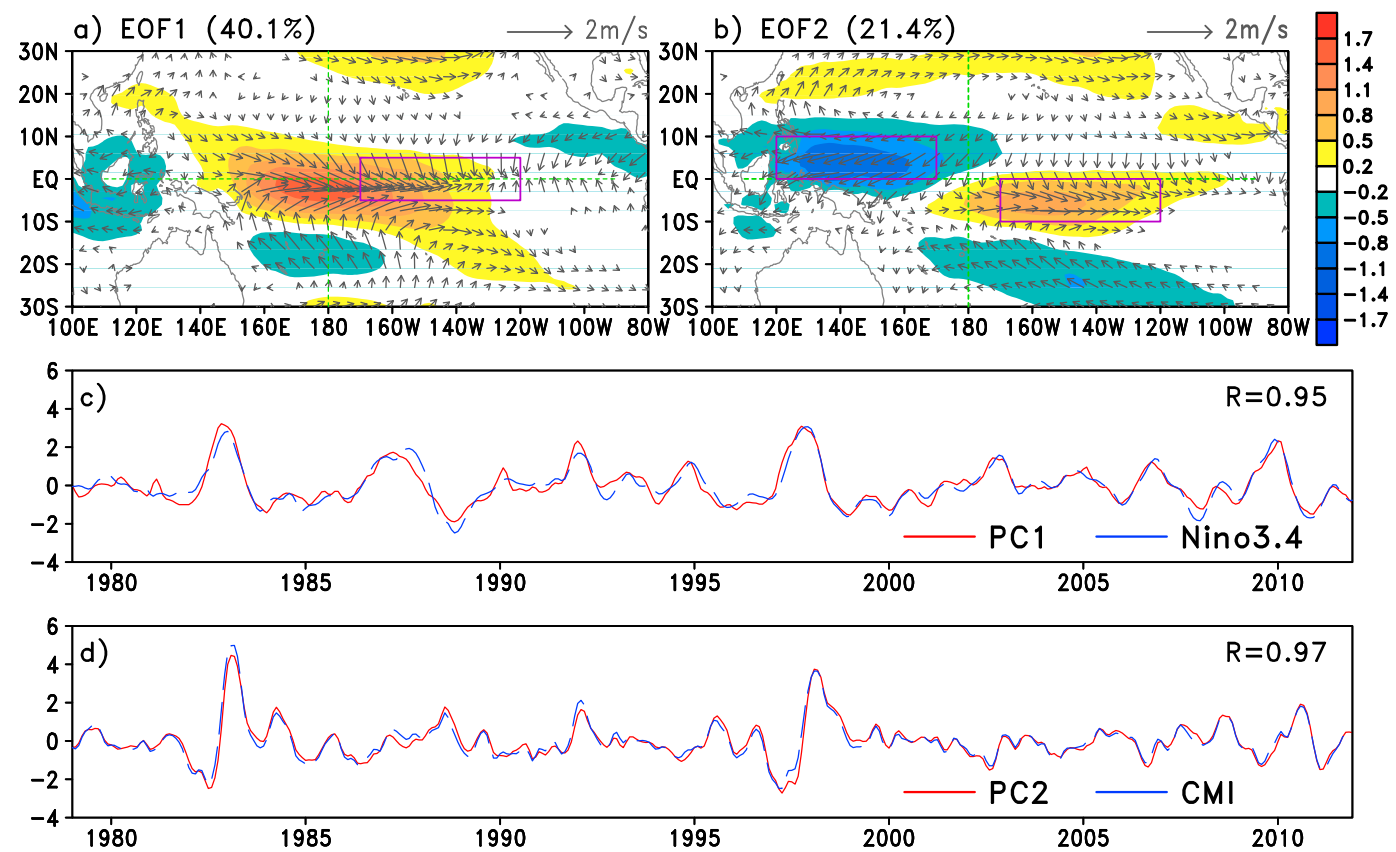

FIG. 2. (a),(b) The leading two EOF spatial patterns and (c),(d) their corresponding normalized PC time series of 10-m wind anomalies $\left(\mathrm{m} \mathrm{s}^{-1}\right)$ over the tropical Pacific. The EOF spatial patterns are obtained by a linear regression of 10-m wind anomalies on the normalized PCs. Wind anomalies less than $0.1 \mathrm{~m} \mathrm{~s}^{-1}$ are not shown. Shading in (a) and (b) displays zonal wind anomalies. The blue line in (c) represents the normalized Niño-3.4 [purple box in (a)] SST anomalies. The blue line in (d) shows the normalized C-mode index (CMI) variability. CMI is defined as the zonal wind difference over the southeastern equatorial Pacific $\left(0^{\circ}-10^{\circ} \mathrm{S}, 120^{\circ}-170^{\circ} \mathrm{W}\right)$ and the northwestern equatorial Pacific $\left(0^{\circ}-10^{\circ} \mathrm{N}, 120^{\circ}-170^{\circ} \mathrm{E}\right)$, as indicated by the purple boxes in (b).

La Niña) events happen (e.g., in the period from 2000 onward in Fig. 2d).

To clearly inspect differences in the atmospheric C-mode response for different ENSO types, we composite the ENSO mature phase reconstructed $10-\mathrm{m}$ wind anomalies associated with the PC1 and PC2 for these types (Fig. 4). For the PC1 reconstructed wind anomalies, all ENSO events show strong wind anomalies centered over the central Pacific (Figs. 4a-c), which is the typical ENSO mature phase wind anomaly pattern (Fig. 2a). The EP and CP El Niño composites both exhibit westerly anomalies in the central Pacific, whereas easterly anomalies appear during the La Niña events. The EP El Niño events have much larger wind anomaly amplitude, which is about twice as strong as that of the CP El Niño and La Niña events.

The PC2 composites display an anomalous low-level anticyclone over the WNP and a cyclonic meridional shear of wind anomalies over the southern central Pacific during the EP El Niño mature phase (Fig. 4d), similar to those shown in Fig. 2b. This wind anomaly pattern tends to result in the southward displacement of the westerly anomalies in the central Pacific. However, the CP El Niño events show an almost opposite wind anomaly pattern to the EP El Niño events in this region (Fig. 4e). The surface wind anomaly pattern associated with the $\mathrm{C}$-mode for $\mathrm{CP} \mathrm{El}$ Niño events seems to inhibit the southward shift of the central Pacific wind anomalies. For La Niña events, the low-level wind anomaly pattern is similar to CP El Niño events with reversed sign (Fig. 4e). This wind anomaly pattern also does not seem to favor the southward movement of the central Pacific easterly anomalies.

To further document the wind anomaly differences associated with various ENSO events, we examine composites of the seasonal evolution of zonal mean $\left(140^{\circ} \mathrm{E}-140^{\circ} \mathrm{W}\right)$ wind anomalies based on the $\mathrm{PC} 1$ and PC2 reconstructions (Fig. 5). For EP El Niño events during the developing phase, strong westerly anomalies prevail over the equator and slightly to the north in the central Pacific. During the peak month around January(1), the strongest wind anomalies move abruptly toward the south of the equator to about $5^{\circ} \mathrm{S}$. In the next few months the maximum wind anomalies prevail in this region and are simultaneously decaying. In contrast, this displacement is not clearly observed for the $\mathrm{CP}$ El Niño and La Niña composites (Figs. 5b,c). The 


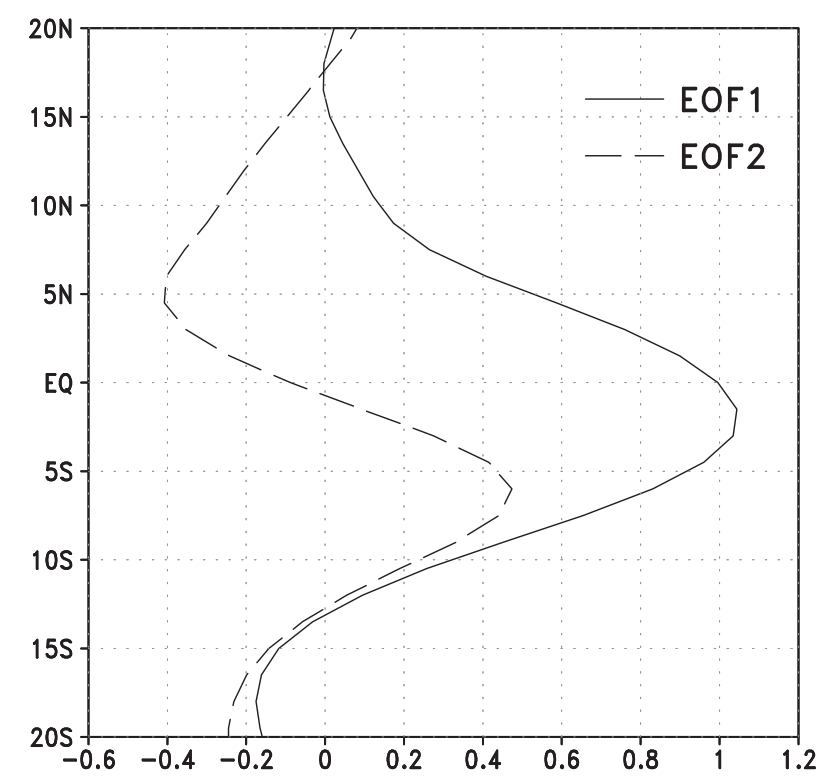

FIG. 3. The meridional structures of zonal mean $\left(140^{\circ} \mathrm{E}-140^{\circ} \mathrm{W}\right)$ $10-\mathrm{m}$ zonal wind anomalies associated with the leading two EOF modes as shown in Fig. 2.

wind anomalies associated with these ENSO types tend to peak during November and December and then decay in the following several months with only a weak southward shift of zonal wind anomalies.

\section{Interevent variability associated with different types of ENSO}

As shown in section 3, different ENSO types exhibit very different characteristics in the associated meridional structure of the central Pacific zonal wind anomalies. Because of the complexity of ENSO in amplitude and spatial structure, the interevent variability of the atmospheric C-mode response is examined here for different ENSO types. For convenience, a C-mode index (CMI) is defined as the zonal wind difference over the southeastern equatorial Pacific $\left(0^{\circ}-10^{\circ} \mathrm{S}, 120^{\circ}-170^{\circ} \mathrm{W}\right)$ and the northwestern equatorial Pacific $\left(0^{\circ}-10^{\circ} \mathrm{N}, 120^{\circ}-170^{\circ} \mathrm{E}\right)$ to describe the C-mode variability (Fig. 2b). The CMI is highly correlated with PC2 $(R=0.97)$ (Fig. 2d). It is important to note that the CMI is designed here to mainly capture the central Pacific southward shift phenomenon, which is one of many features of the atmospheric C-mode response in the Indo-Pacific region (Stuecker et al. 2015). Not all of these features can be captured by a single index. The seasonal evolution of the Niño-3.4 index and CMI during three EP El Niño events, two of which are extreme events (i.e., 1982/83 and 1997/98), is shown in Fig. 6. These three EP El Niño events begin during spring season, peak in the winter months from November (0) to January (1), and decay in the following spring months (Fig. 6). The CMI has a) EP El Nino-PC1

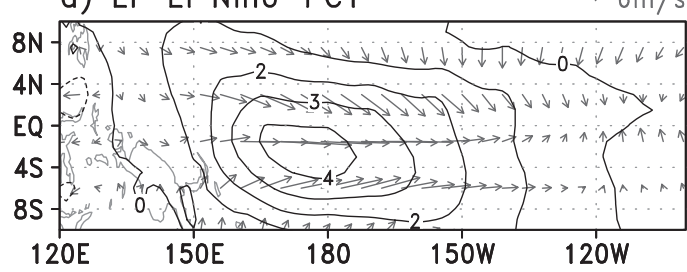

b) $\mathrm{CP}$ El Nino-PC1 $\longrightarrow 3 \mathrm{~m} / \mathrm{s}$

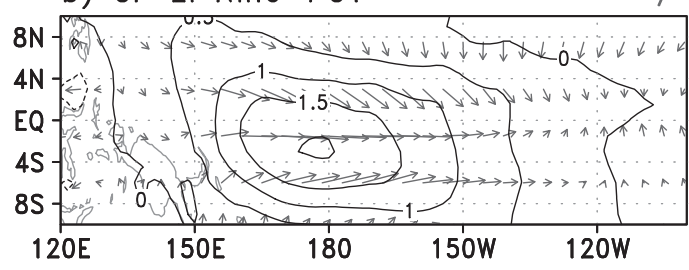

c) La Nina-PC1 $\longrightarrow 3 \mathrm{~m} / \mathrm{s}$

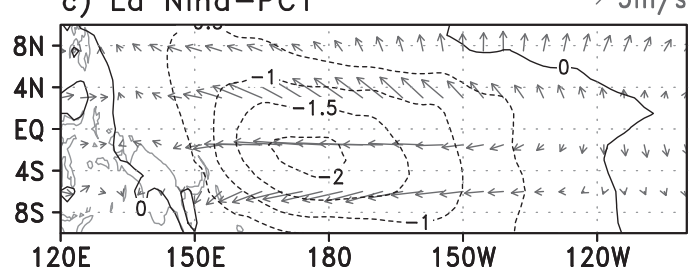

d) EP El Nino-PC2

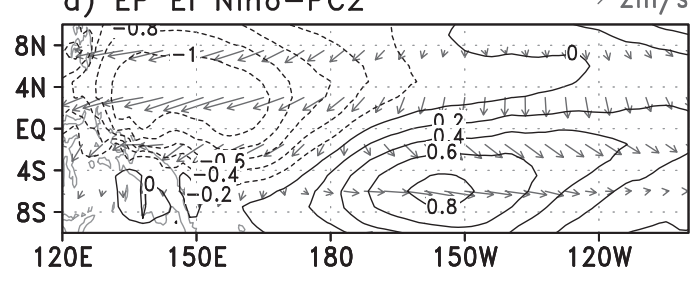

e) $\mathrm{CP}$ El Nino-PC2

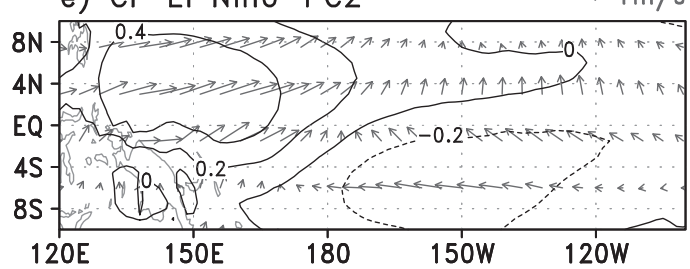

f) La Nina-PC2

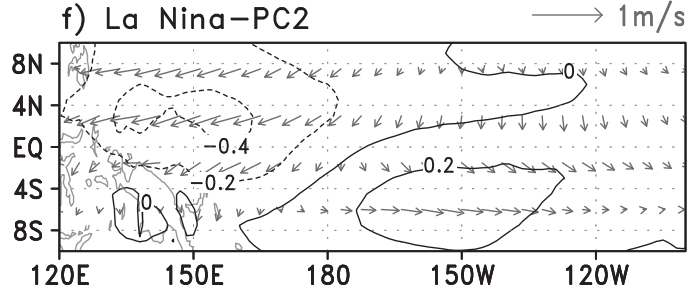

FIG. 4. The (left) PC1 and (right) PC2 reconstructed 10-m wind anomalies (vector in $\mathrm{m} \mathrm{s}^{-1}$ ) during (a),(d) EP El Niño, (b),(e) CP El Niño, and (c),(f) La Niña mature phase averaged from September(0) to February(1). The contours indicate the corresponding zonal wind anomalies. 

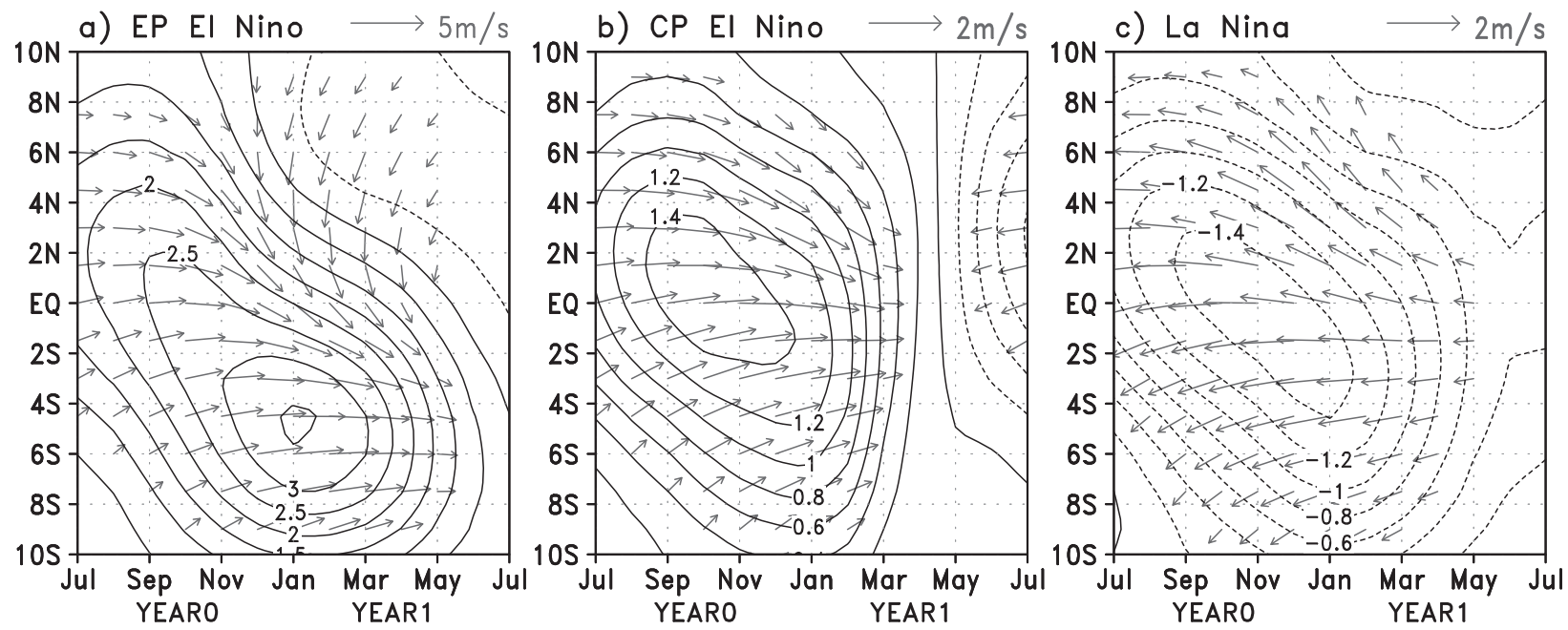

FIG. 5. Latitude-time sections of zonal mean $\left(140^{\circ} \mathrm{E}-140^{\circ} \mathrm{W}\right) 10-\mathrm{m}$ wind anomalies (vector in $\left.\mathrm{m} \mathrm{s}^{-1}\right)$ reconstructed by the leading two PCs for (a) EP El Niño, (b) CP El Niño, and (c) La Niña events. The contours indicate the corresponding zonal wind anomalies.

negative values during the El Niño developing phase, which then rapidly reverses its sign around September. The CMI reaches its maximum intensity during the late winter or early spring, indicating the strong southward shift of the central Pacific wind anomalies. The CMI peaks about three months later than the Niño-3.4 index in the composite (Fig. 6d). All three EP El Niño events exhibit a similar evolution for the relationship between the El Niño and C-mode indices.

In contrast, CP El Niño events start developing around summer, reach their mature phase approximately in November, and usually decay by late spring (Fig. 7f). Each CP El Niño event features a similar evolution (Fig. 7), analogous to the evolution of the EP El Niño events, but with a relatively shorter duration. Associated with the $\mathrm{CP}$ El Niño events, the composited CMI stays negative through the event developing and mature phases, and reverses its sign about 2-3 months later (Fig. 7f). Subsequently, the CMI reaches its maximum during the decaying summer. Most events are characterized by a similar CMI evolution, although the turnaround of the 2002/03 and 2009/10 events occurs slightly earlier. In contrast to EP El Niño events, a remarkable difference appears in the $\mathrm{C}$-mode evolution, even showing an opposite sign in the period approximately from September (0) to February (1). For most of the CP El Niño events only a weak CMI signal is detected during the mature winter and decaying spring months, suggesting that no obvious meridional shift of wind anomalies occurs. It is found that the meridional movement of zonal winds becomes stronger with increasing El Niño amplitude (McGregor et al. 2013). Therefore, the meridional shift of wind anomalies during CP El Niño events is weak since their amplitude is much weaker than that of EP types.
The seasonal evolution of the Niño-3.4 index and CMI for all La Niña events selected in section 2 and their composite is shown in Fig. 8. Usually, La Niña events begin to develop over the equatorial Pacific during the summer season, reach their peak around December, and then decay afterward (Fig. 8h). Two La Niña events $(1983 / 84,1998 / 99)$ have a second peak in the subsequent winter (Figs. 8a,d). Here, only the 1998/99 La Niña is shown as an example to exhibit its evolution with reemergence in consecutive winters. Interestingly, both long La Niña events followed the two well-known extreme El Niño events (i.e., 1982/83, 1997/98), suggesting a possible linkage to the strong discharge of equatorial Pacific heat content during the preceding ENSO warm events. For the C-mode, most La Niña events have a positive sign before its peak month with maximum values normally occurring during the autumn months (Fig. 8). However, the CMI is reduced rapidly with no clear peak during the 1983/84 and 1998/99 events (Figs. 8a,d). After the La Niña mature phase, the CMI is close to zero for most of the events (Fig. 8). However, the 1983/84 La Niña event has a relatively strong positive peak and the 2010/11 La Niña event shows a strong negative peak during their decaying spring season. A weak CMI during the La Niña peak phase and the following months for almost all events indicates no strong southward displacement of the equatorial wind anomalies.

We next inspect the relationship between ENSO and its related C-mode response during ENSO events using an ENSO/C-mode scatterplot (Fig. 9). Here the periods December(0)-January(1) and February(1)-April(1) are approximately defined as the ENSO and C-mode mature phases, respectively, since the CMI reaches its maximum during ENSO decaying phases. The CMI 
a) $1982 / 1983$

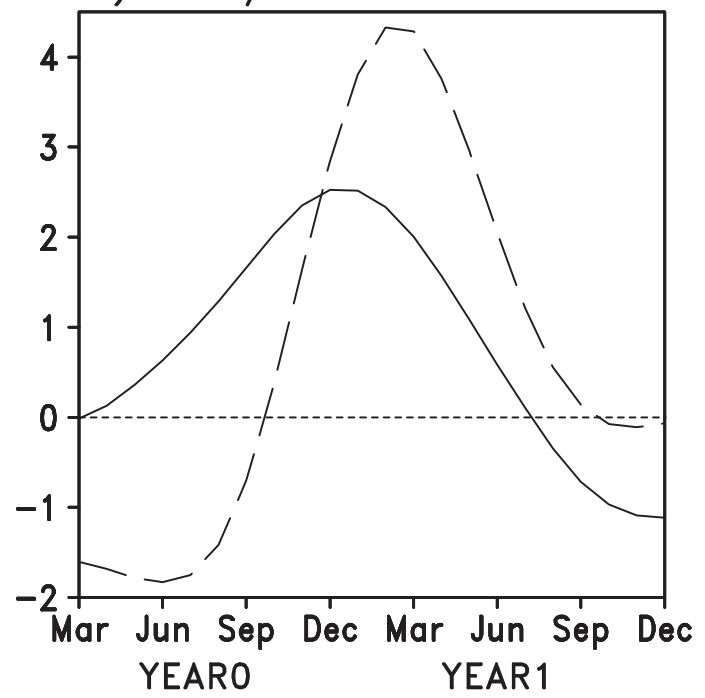

c) $1997 / 1998$

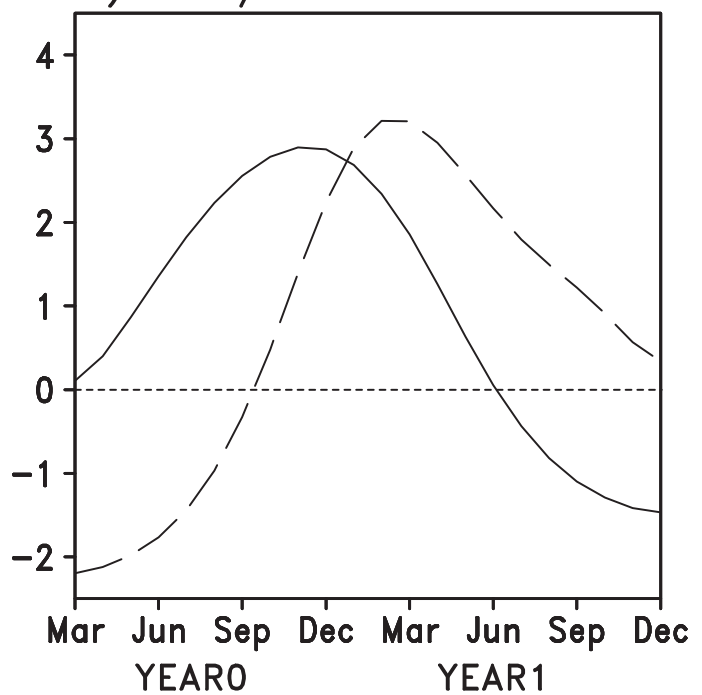

b) $1991 / 1992$

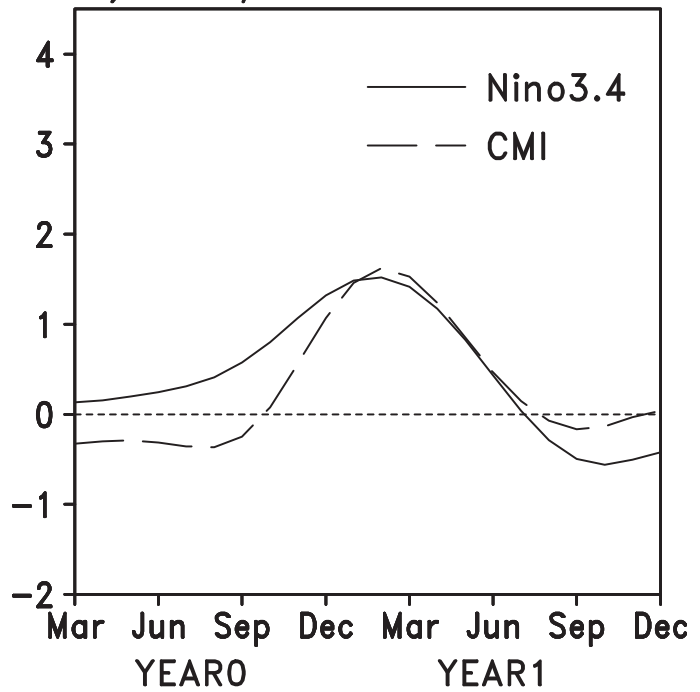

d) composite

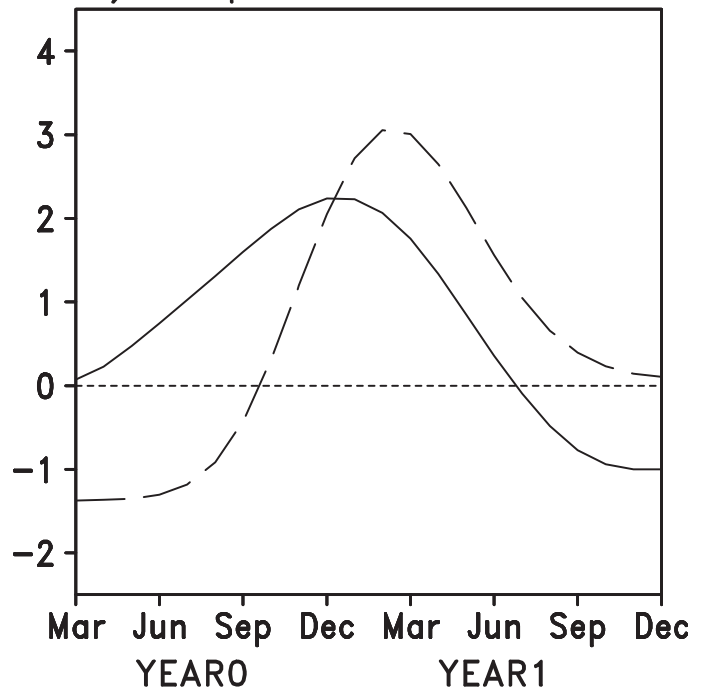

FIG. 6. Monthly evolution of the Niño-3.4 SST anomalies and CMI for (a) 1982/83, (b) 1991/92, and (c) 1997/98 EP El Niño events, and (d) their composite.

values are above 1.8 standard deviations for all EP El Niño events, indicating a robust southward displacement of wind anomalies occurring during these EP El Niño decaying phases. For the CP El Niño events, a near-zero CMI suggests that no strong meridional displacement of the equatorial wind anomalies occurs during their decaying phase. A previous study (Ohba 2013) emphasized the important effect of El Niño's amplitude on the zonal structure of atmospheric responses over the equatorial Pacific. As shown in Fig. 9, however, the CMI of all CP El Niño events is near zero despite the large variation in amplitude of these events, suggesting no relation between the CMI and
CP El Niño amplitude. Similar to CP El Niño events, no significant meridional displacement of wind anomalies appears during the La Niña decaying phase, but with larger interevent diversity. Different ENSO flavors are characterized by contrasting wind anomaly patterns associated with the $\mathrm{C}$-mode responses. The similar nonlinear relationship between other features for different types of ENSO is also shown in previous studies (e.g., Cai et al. 2012, 2014), which demonstrate a huge difference in meridional movements of the Southern Hemisphere South Pacific convergence zone (SPCZ) and Northern Hemisphere intertropical convergence zone (ITCZ). 

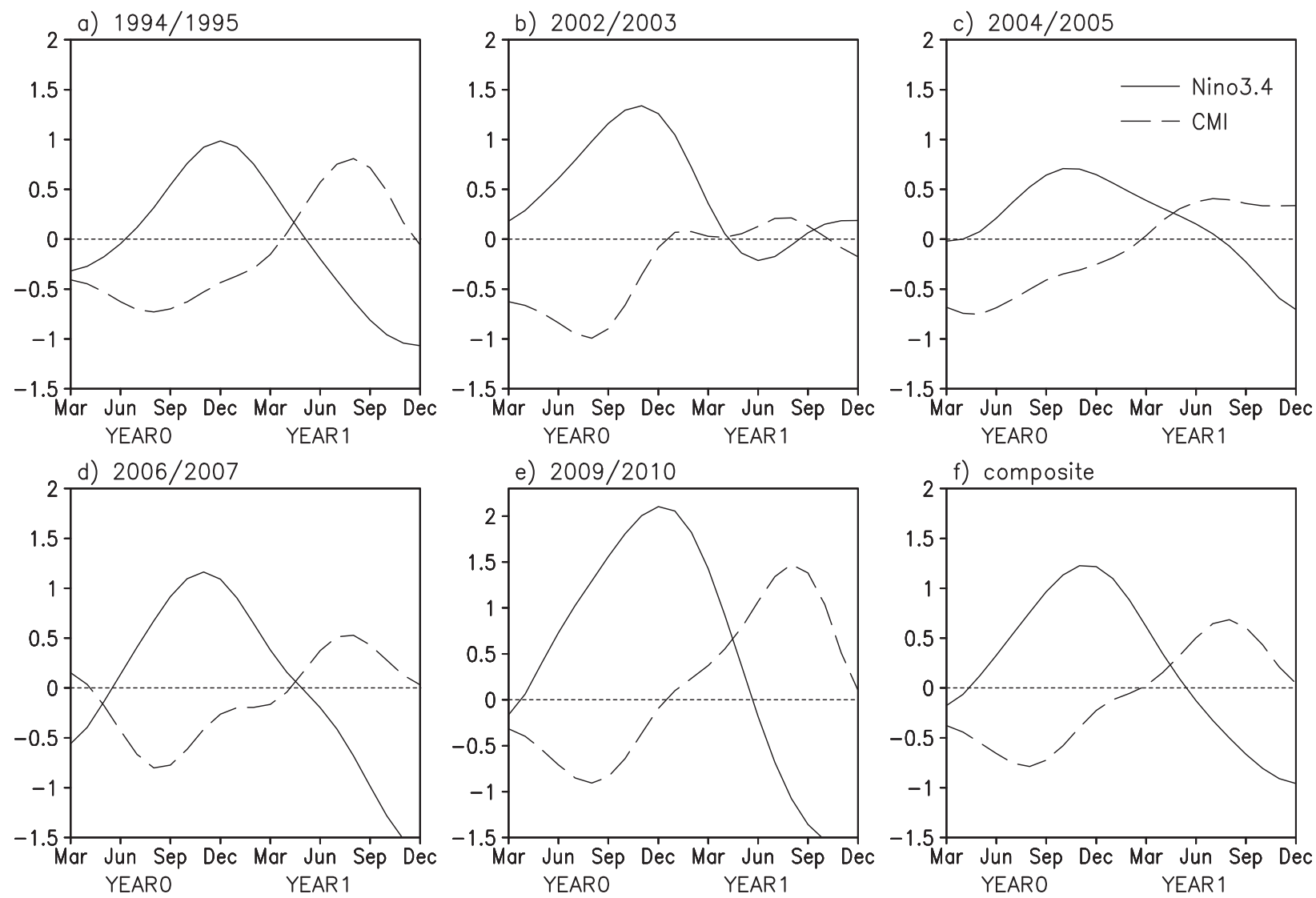

FIG. 7. Monthly evolution of the Niño-3.4 SST anomalies and CMI for the (a) 1994/95, (b) 2002/03, (c) 2004/05, (d) 2006/07, and (e) 2009/10 CP El Niño events, and (f) their composite.

\section{Possible mechanism for the contrasting meridional shift in zonal wind structure associated with different ENSO types}

According to the analyses above, different ENSO types exhibit contrasting features in the southward displacement of the central Pacific wind anomalies. Since the wind anomalies are closely associated with those in convection, we explore the central Pacific convection changes for different ENSO types and phases. The composite of zonal-mean surface wind, SST, and precipitation anomalies during ENSO evolution are shown in Fig. 10. We choose a zonal mean region near the date line $\left(140^{\circ} \mathrm{E}-\right.$ $\left.140^{\circ} \mathrm{W}\right)$ as the action center of ocean-atmosphere interaction. It is located over the eastern edge of the western Pacific warm pool, where the ENSO SST anomalies and the background SSTs are both relatively strong. In comparison, the associated atmospheric response is much weaker over the eastern equatorial Pacific because even large SST anomalies are usually not able to initiate strong convection anomalies in a region with low background climatological SSTs.
The two El Niño types and La Niña exhibit almost the same SST anomaly features including its evolution and spatial pattern (Fig. 10). The ENSO SST anomalies are meridionally quasi-symmetric about the equator with a slight southward shift, consistent with previous studies (Zhang et al. 2009, 2013a; Zhang and Jin 2012). Unlike the SST anomaly pattern evolution, a robust southward shift of wind anomalies appears during the EP El Niño peak and decaying phase (Fig. 10a). In contrast, only a weak southward shift of wind anomalies is observed during the CP El Niño and La Niña composites (Figs. 10b,c; note also the much smaller unit vector used in the $\mathrm{CP}$ and $\mathrm{La}$ Niña composites). These wind anomaly features are almost the same as those of Fig. 5, based on the reconstructed wind anomalies by $\mathrm{PC} 1$ and $\mathrm{PC} 2$. Correspondingly, the meridional structure of convection anomalies during EP El Niño events is significantly different from those during CP El Niño and La Niña events (Fig. 10). No meridional movement of precipitation anomalies is observed for the CP El Niño and La Niña events (Figs. 10b,c). The associated precipitation anomalies are quasisymmetric about the equator, associated with no wind 

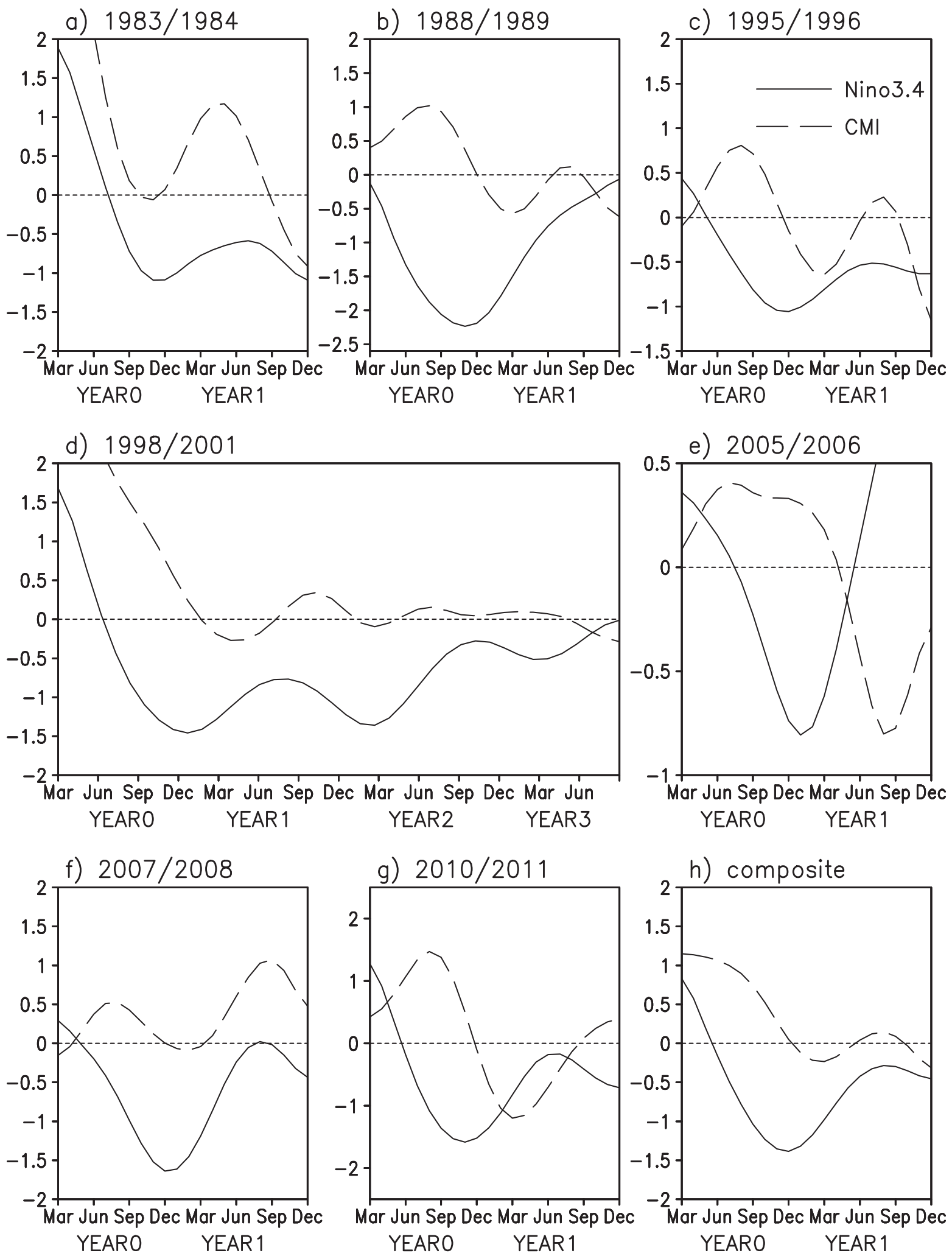

FIG. 8. Monthly evolution of the Niño-3.4 SST anomalies and CMI for the (a) 1983/84, (b) 1988/89, (c) 1995/96, (d) 1998-2001, (e) 2005/06, (f) 2007/08, and (g) 2010/11 La Niña events, and (h) their composite. 


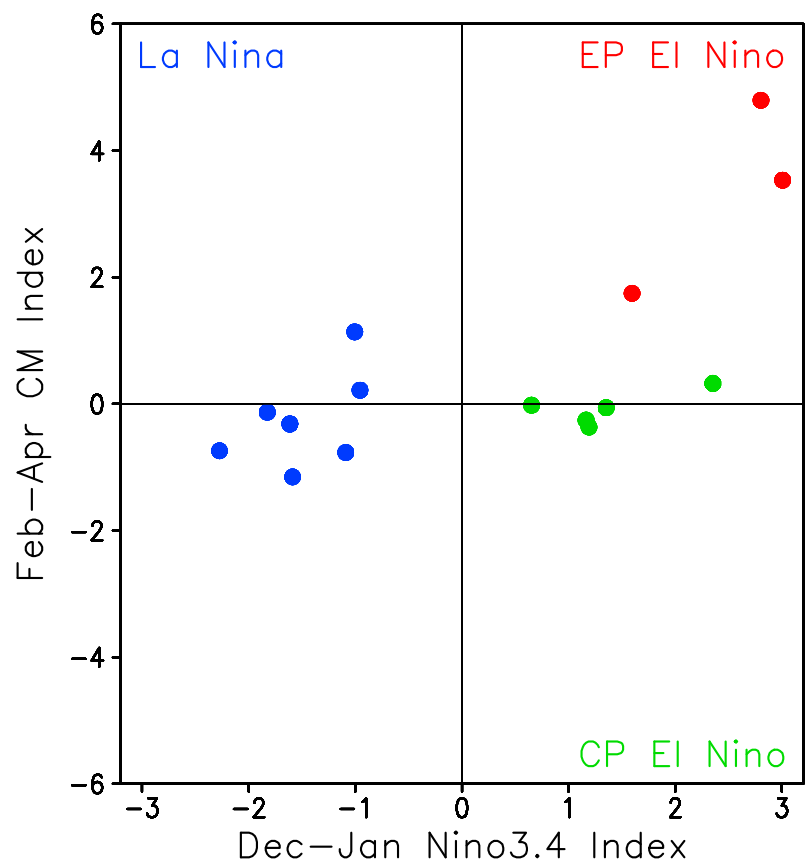

FIG. 9. Scatterplots of the December(0)-January(1) normalized Niño-3.4 index with February(1)-April(1) normalized CMI during EP El Niño (red), CP El Niño (green), and La Niña (blue) events.

anomaly shift. During the EP El Niño developing phase before November(0), positive precipitation anomalies emerge centered on the equator (Fig. 10a). In subsequent months, the positive precipitation anomalies are rapidly displaced southward with a center at about $5^{\circ} \mathrm{S}$. Simultaneously, strong negative precipitation anomalies occur north of the equator. These meridionally antisymmetric precipitation anomalies tend to occur during the EP El Niño peak month and persist for several months, and are suggested to be responsible for the southward shift of wind anomalies (see also Stuecker et al. 2015).

It seems that the convection anomalies can be used to explain the southward shift of wind anomalies. However, there remains the issue of why the CP El Niño and La Niña events produce a very different meridional structure of precipitation anomalies compared to the EP El Niño events. To understand their differences in precipitation response to SST anomalies, the climatological seasonal SST, precipitation, and surface winds over the tropical Pacific are examined for periods September(0)-December(0) and January(1)April(1), approximately defined as the ENSO developing and decaying months (Fig. 11). Here, the meridional migration of zonal wind anomalies is the focus through intercomparison between these two periods. Over the western tropical Pacific, the warmest SSTs shift from north of the equator during the summer months to south of the equator during the winter months along with the seasonal march of solar insolation. During September-December, the high SSTs over the western Pacific are quasi-symmetric about the equator with an eastward extension of warm SSTs south of the equator. There are two belts of warm SSTs observed off the equator, one being the ITCZ and the other the SPCZ. The ITCZ near $9^{\circ} \mathrm{N}$ elongates zonally from the western Pacific to the western coast of Central America. The
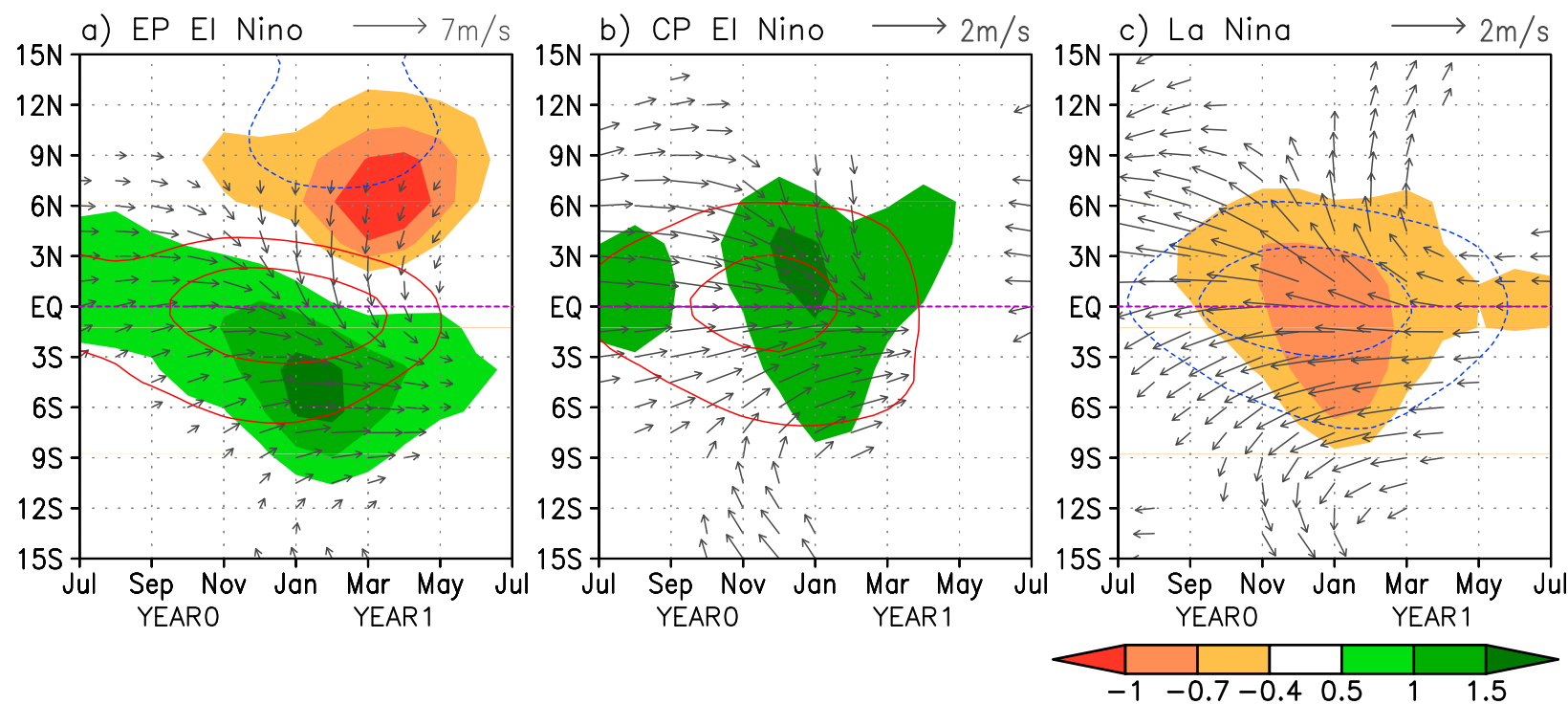

FIG. 10. Latitude-time sections of composite zonal mean $\left(140^{\circ} \mathrm{E}-140^{\circ} \mathrm{W}\right) 10-\mathrm{m}$ wind anomalies (vector in $\left.\mathrm{m} \mathrm{s}^{-1}\right)$, SST anomalies (contours in ${ }^{\circ} \mathrm{C}$ ), and precipitation anomalies (shading in $\mathrm{mm} \mathrm{day}^{-1}$ ) for (a) EP El Niño, (b) CP El Niño, and (c) La Niña events. The red and blue contours indicate positive values of $0.3^{\circ}$ and $0.6^{\circ} \mathrm{C}$ and negative values of $-0.3^{\circ}$ and $-0.6^{\circ} \mathrm{C}$, respectively. 

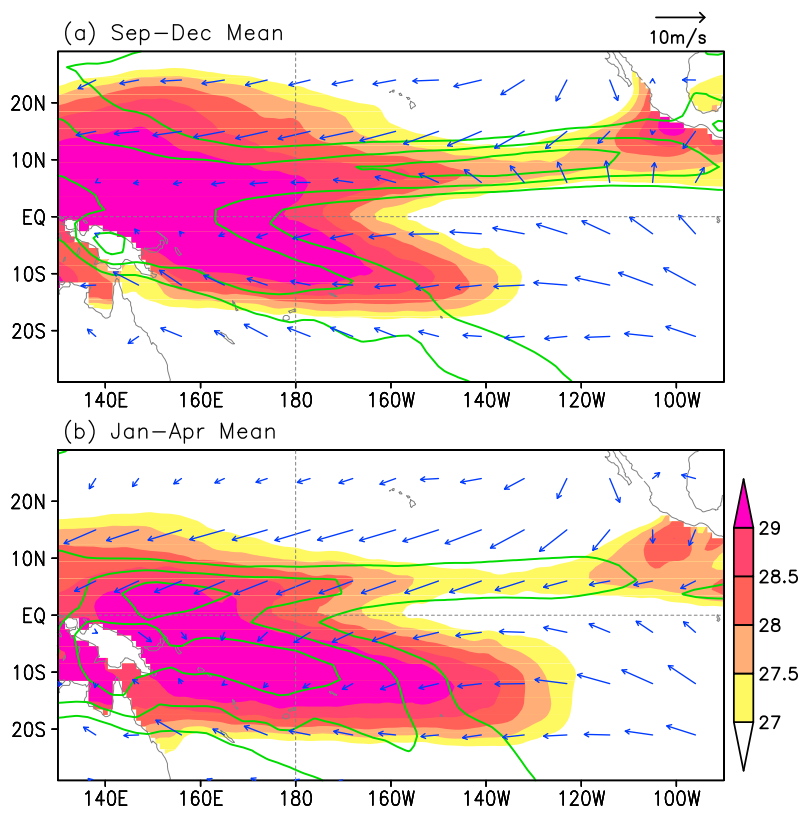

FIG. 11. Climatological SST (shading in ${ }^{\circ} \mathrm{C}$ ), precipitation (green contours in values of 4,6 , and $8 \mathrm{~mm}$ day $^{-1}$ ), and $10-\mathrm{m}$ wind (vector in $\mathrm{m} \mathrm{s}^{-1}$ ) for the (a) September-December and (b) January-April average.

SPCZ tilts slightly southeastward and stays to the west of $\sim 130^{\circ} \mathrm{W}$. The climatological cold tongue of SSTs separates these two convergence zones over the eastern equatorial Pacific.

In comparison with the September-December mean state, the January-April warm SSTs over the western Pacific migrate south by about $10^{\circ}$ latitude based on the $28^{\circ} \mathrm{C}$ isotherm in the Northern Hemisphere (Fig. 11b). The $28^{\circ} \mathrm{C}$ isotherm is the approximate convection threshold that defines the warm pool extent (Gadgil et al. 1984; Graham and Barnett 1987). For the JanuaryApril mean state, warm SSTs above $28^{\circ} \mathrm{C}$ are located mainly south of the equator, where the eastern boundary extends east toward $\sim 135^{\circ} \mathrm{W}$. The SPCZ SSTs exhibit stronger amplitude and larger zonal and meridional extension during the period January-April than those during the period September-December. Accordingly, the strong wind convergence occurs mainly over the southwestern tropical Pacific, collocated with the precipitation maxima (Fig. 11b). The eastern Pacific ITCZ also shifts equatorward with reduced SST amplitude.

We will now compare EP and CP El Niño structures in Figs. 12 and 13, respectively. For the EP El Niño September(0)-December(0), warm SST anomalies occur over the equatorial eastern Pacific and extend from the coast of South America to the date line (Fig. 12a). The positive SST anomalies decay away from the equator to both the south and north, exhibiting a meridionally quasi-
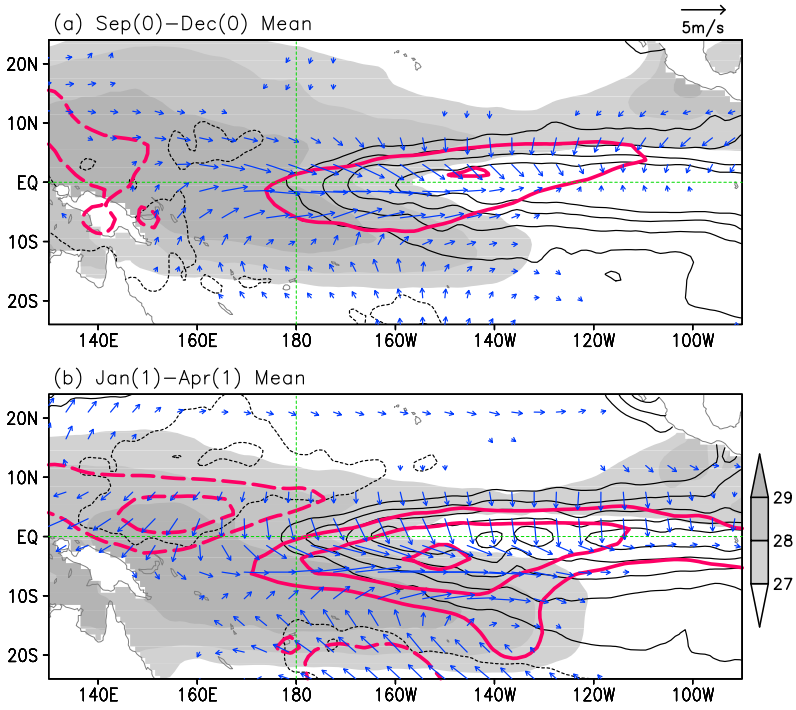

FIG. 12. EP El Niño composite SST anomalies (black contours at intervals of $0.4^{\circ} \mathrm{C}$ with zero contours omitted), precipitation anomalies (red contours at intervals of $1 \mathrm{~mm}$ day $^{-1}$ with zero contours omitted), and 10-m wind anomalies (vector in $\mathrm{m} \mathrm{s}^{-1}$; not shown when wind speed is less than $\left.0.5 \mathrm{~m} \mathrm{~s}^{-1}\right)$ for the (a) September(0)-December(0) and (b) January(1)-April(1) average. Shading indicates climatological SST for the (a) SeptemberDecember and (b) January-April average.

symmetric structure. The warming SST anomalies superimposed on the background SSTs cause enhanced precipitation over the central and eastern equatorial region with a slight southwest-northeast tilt. Correspondingly, westerly anomalies appear across the equator with strong anomalies occurring over the central equator. Over the western equatorial Pacific, the precipitation is reduced because cold SST anomalies inhibit the convection there. When the EP El Niño events enter their decaying phase (Fig. 12b), the warm SST anomaly structure over the eastern tropical Pacific is similar to that of September(0)December(0). As a response to the SST anomalies, the precipitation anomalies are antisymmetric about the equator and shift south of the equator, very different from those during September(0)-December(0). Correspondingly, the westerly anomalies are also displaced southward, as described earlier. However, how do quasi-symmetric SST anomalies produce an antisymmetric atmospheric response? The seasonal migration of the background warm SSTs has been suggested to play a dominant role on the southward displacement of the atmospheric anomalies (e.g., Spencer 2004; Stuecker et al. 2015). For the January(1)April(1) mean, the climatological SSTs exhibit a high meridional antisymmetry about the equator with much warmer water south of the equator than that north of the equator (Figs. 11b and 12b). Therefore, the SST anomalies over the central Pacific can trigger convection anomalies 

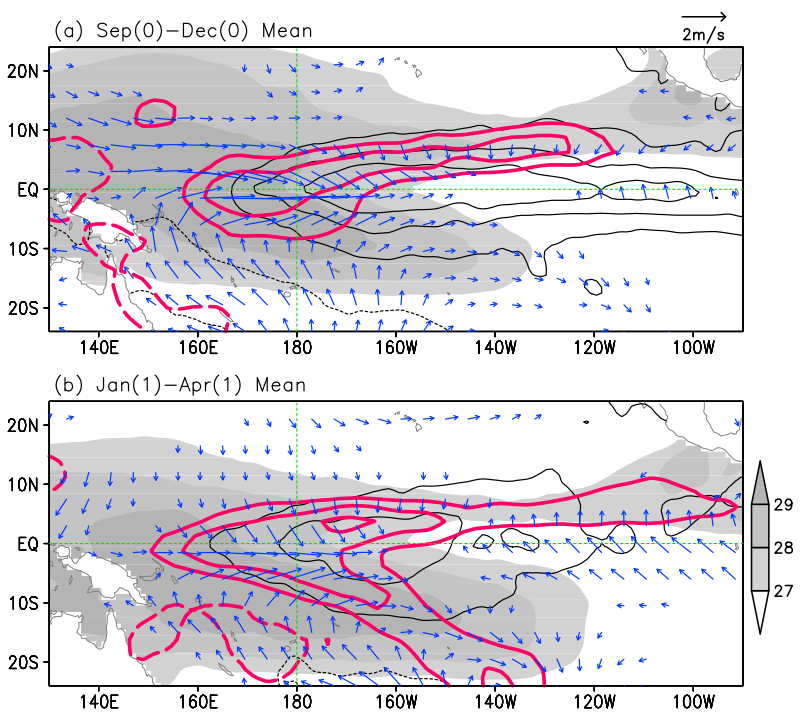

FIG. 13. As in Fig. 12, but for CP El Niño composites. Intervals of SST and precipitation anomalies are $0.3^{\circ} \mathrm{C}$ and $0.5 \mathrm{~mm} \mathrm{day}^{-1}$, respectively. Wind anomalies less than $0.3 \mathrm{~m} \mathrm{~s}^{-1}$ are not shown.

more easily in the south than that in the north. Over the western Pacific, the cold SST anomalies are displaced north with a center located over the western North Pacific, possibly due to the local air-sea interaction (Wang et al. 2000). The WNP negative SST anomalies can reduce the total SSTs toward values less than $28^{\circ} \mathrm{C}$ and thus tend to inhibit local convection, causing anticyclonic anomalies there. A recent study documented that the anomalous anticyclone over the WNP region is mostly related to the enhanced precipitation south of the equator, which favors atmospheric subsidence through the anomalous meridional circulation (Stuecker et al. 2015).

During the CP El Niño mature season, the SST anomaly center is displaced westward covering the central Pacific compared to EP El Niño events (Fig. 13a). In terms of the meridional structure, the SST anomalies are quasisymmetric about the equator, similar to those during EP El Niño events. No strong negative SST anomaly occurs over the equatorial western Pacific. Along with the westward displacement of the maximum SST anomalies, the associated precipitation response is also shifted westward, covering the equatorial central Pacific and extending slightly northeastward toward the eastern ITCZ. During the CP El Niño decaying phase, the intensity of SST anomalies is weakened and the maximum SST anomalies are located near the date line. The positive SST anomalies are also highly symmetric about the equator (Fig. 10b). In contrast to EP El Niño conditions, the maximum precipitation anomalies emerge mainly at the equatorial central Pacific expanding northeast and southeast. Although the background SSTs are warmer in

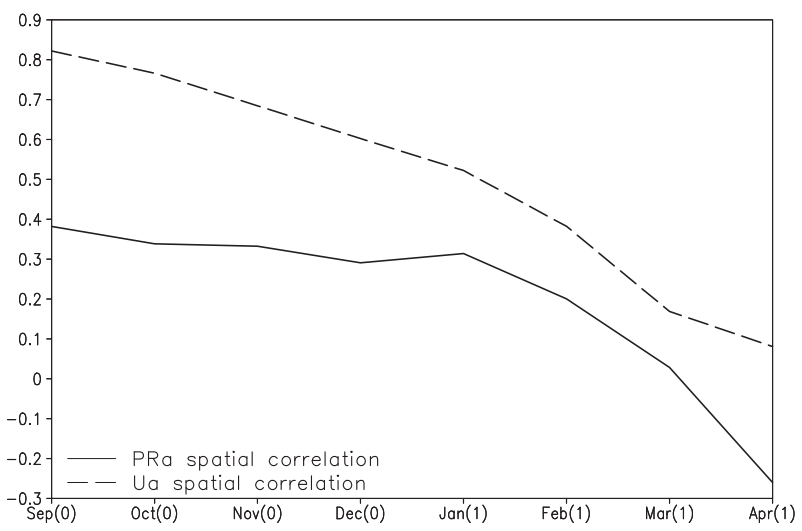

FIG. 14. Spatial correlation between EP and CP El Niño anomaly patterns of precipitation (solid line) and surface zonal wind (dashed line) over the equatorial Pacific $\left(25^{\circ} \mathrm{S}-25^{\circ} \mathrm{N}, 130^{\circ} \mathrm{E}-90^{\circ} \mathrm{W}\right)$ from El Niño development to decay [September(0) to April(1)]. A 3-month running mean is applied.

the south than in the north, the warm SSTs north of the equator in the western Pacific are still around $28.5^{\circ} \mathrm{C}$ (Fig. 13b). When the SST anomalies extend farther west into the warm pool, they can easily excite strong convection anomalies both to the north and south of the equator. Hence, the precipitation anomalies are highly symmetric about the equator. Consequently, no strong meridional shift of wind anomalies is observed for CP El Niño events. In conclusion, the zonal position of the SST anomaly structure and consequent impact on the meridional structure of total SST is crucially important in determining the meridional atmospheric response. The difference in meridional movements of atmospheric response between the EP and CP El Niño is partly supported by their spatial correlation (Fig. 14). For example, the spatial correlation of precipitation anomalies over the tropical Pacific is significantly decreased after January (1).

The SST anomaly center during La Niña events is shifted westward compared to EP El Niño events. The La Niña SST anomaly structure resembles CP El Niño events with a reversed sign. Hence, the atmospheric response during La Niña events is expected to be similar to those of CP El Niño events with a reversed sign. Compared to the La Niña developing phase, there is no strong meridional movement in the atmospheric response during the decaying phase, which is highly symmetric about the equator (Fig. 15). Therefore, we conclude that the southward shift of the atmospheric response depends crucially on the zonal position of the SST structure during an event transition phase.

\section{Conclusions and discussion}

Previous studies have demonstrated that a strong southward shift of central Pacific zonal wind anomalies accompanies the termination process of ENSO (e.g., 


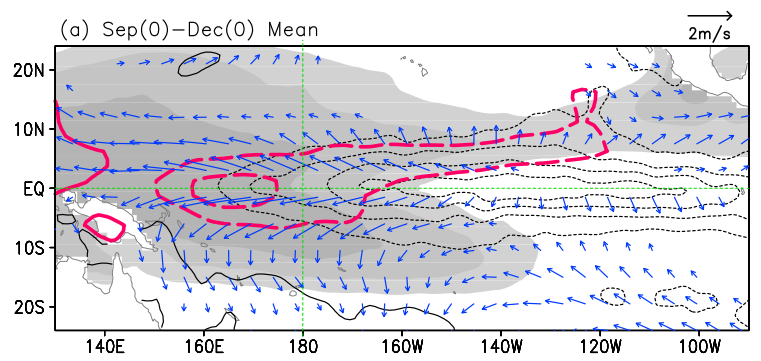

(b) Jan(1)-Apr(1) Mean

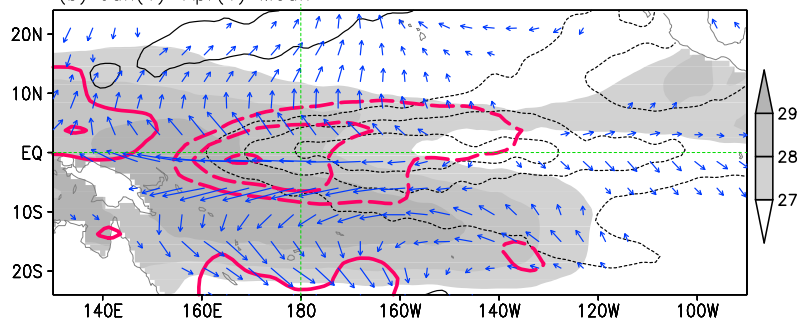

FIG. 15. As in Fig. 13, but for La Niña composites.

Harrison and Larkin 1998), which has been demonstrated to occur by an interaction between the annual cycle and the ENSO variability (e.g., Stuecker et al. 2013). In this study, we investigate the characteristics of the zonal wind anomaly southward shift for different ENSO types. During the EP El Niño decaying months, the southward wind displacement occurs despite meridionally quasi-symmetric SST anomalies. The seasonal southward movement of the background warm SSTs allows enhancement of precipitation south of the equator and thus causes the southward shift of the equatorial zonal wind anomalies. However, the strong southward movement of central Pacific wind anomalies is not clearly observed during the decaying phase of $\mathrm{CP}$ El Niño events. CP El Niño events display a farther westward location of the SST anomalies compared to EP El Niño events. Farther west, the background SSTs north of the equator are warm enough (around $28^{\circ} \mathrm{C}$ ) for the occurrence of deep convection. Hence, relatively small SST anomalies can as easily excite convection anomalies north of the equator as south of the equator during CP El Niño events. Positive precipitation anomalies are highly symmetric about the equator, despite warmer background SSTs in the Southern Hemisphere during the period January(1)-April(1). Consequently, no clear southward displacement of central Pacific wind anomalies can be observed during the CP El Niño decaying phase. La Niña events exhibit a SST anomaly zonal structure similar to CP El Niño events with a reversed sign. Likewise, no strong meridional movements of the equatorial precipitation and wind anomalies occur during the La Niña decaying phase. Therefore, the southward movement of the ENSO ocean-atmospheric action center is crucially dependent on the zonal location of the SST anomalies.

The observed analyses show that the atmospheric response exhibits a high degree of sensitivity to the zonal position of ENSO SST anomalies. It is a big challenge for state-of-the-art models to capture the contrasting convection anomalies associated with different ENSO types. The global atmosphere model developed by the Met Office (Met Office Unified Model Global Atmosphere 6.0, or GA6.0) is taken as an example model to examine the performance in simulating different atmospheric responses to the two El Niño types. The GA6.0 model is the latest version with resolutions at N96 $(\sim 130 \mathrm{~km})$ and $\mathrm{N} 216(\sim 60 \mathrm{~km})$, and with 85 vertical levels. The experiments are forced with Atmospheric Model Intercomparison Project (AMIP)-style SST boundary conditions from 1979 to 2008 (thus not including the 2009/10 El Niño event). The EP and CP El Niño composite atmospheric response simulated by the N216 GA6.0 model is shown in Fig. 16. Obvious biases exist in simulated atmospheric responses to El Niño, such as a too strong atmospheric response and slightly farther westward location of positive precipitation anomalies (not shown). Despite these biases, the GA6.0 model has the ability to simulate different atmospheric responses in zonal location associated with two types of El Niño (not shown). For the meridional migration, the observed southward displacement of the atmospheric response during the EP El Niño decaying phase is well captured by the GA6.0 model (Fig. 16a). No strong southward displacement of the atmospheric response is found during the CP El Niño events (Fig. 16b), which is consistent with the observations (Fig. 10b). The GA6.0 model experiments realistically simulate the contrasting evolution of the atmospheric response meridional structures during the EP and CP El Niño events. The response in the lower-resolution (N96) GA6.0 simulation (not shown) is almost the same as for the higherresolution N216 version. This suggests that the GA6.0 models have high skill in replicating the central Pacific SST-convection relation during warm ENSO events. However, it is unclear whether most other state-of-theart atmospheric models can reproduce these contrasting features in meridional migration of atmospheric response for two different El Niño types. Further investigation of the model performances and possible causes for simulated biases should be conducted in the future to improve the associated simulation skills of atmospheric models. Since one-way forcing from ocean to atmosphere is involved in the AMIP experiments, coupled experiments [e.g., the Coupled Model Intercomparison Project (CMIP)] are expected to better capture realistic atmospheric responses. Coupled ocean- 

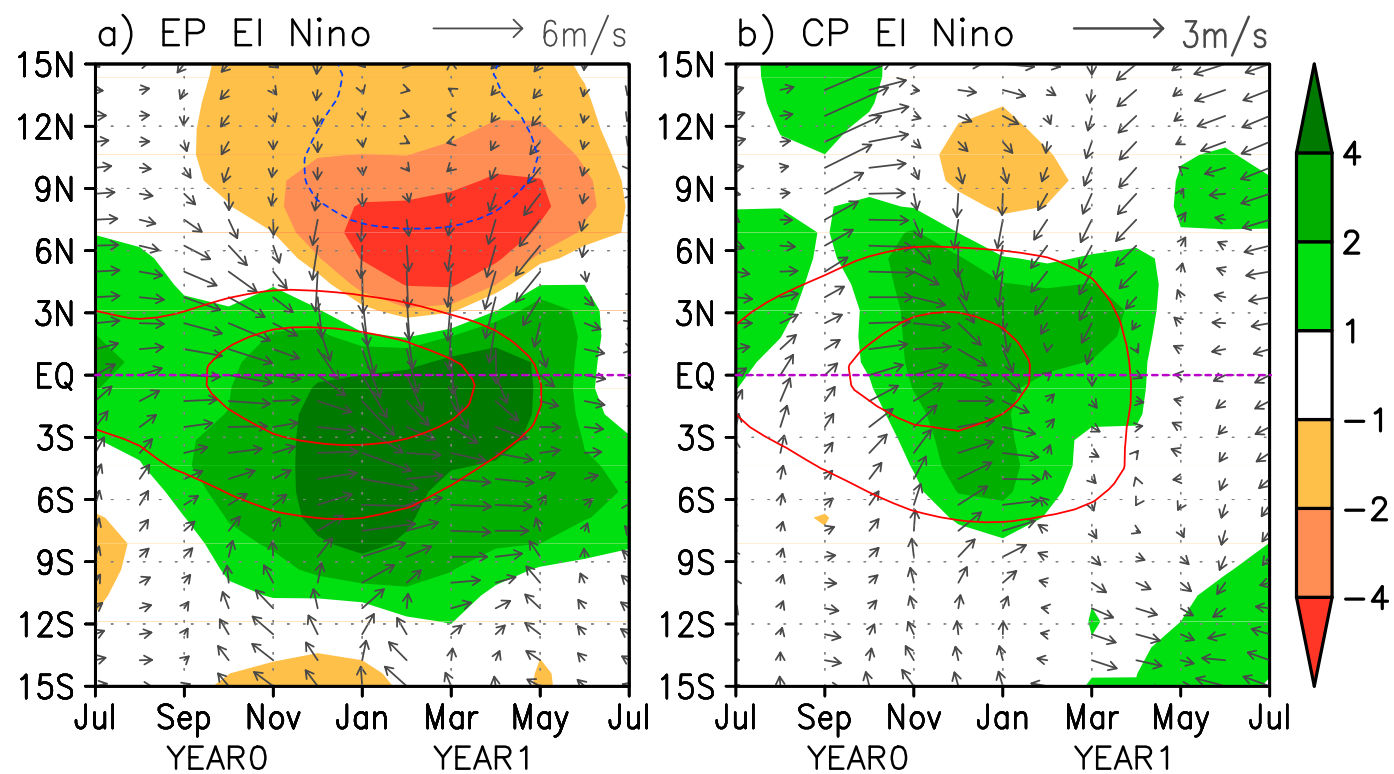

FIG. 16. Model simulated latitude-time sections of composite zonal mean $\left(140^{\circ} \mathrm{E}-140^{\circ} \mathrm{W}\right) 10-\mathrm{m}$ wind anomalies (vector in $\mathrm{m} \mathrm{s}^{-1}$ ), SST anomalies (contours in ${ }^{\circ} \mathrm{C}$ ), and precipitation anomalies (shading in mm day ${ }^{-1}$ ) for (a) EP El Niño and (b) CP El Niño events. The red and blue contours indicate positive values of $0.3^{\circ}$ and $0.6^{\circ} \mathrm{C}$ and negative values of $-0.3^{\circ}$ and $-0.6^{\circ} \mathrm{C}$, respectively. The Met Office GA6 model at N216 resolution is used.

atmosphere feedbacks should lead to a more realistic atmospheric response by including atmospheric feedbacks on the SSTs. However, current coupled models are not able to simulate the two El Niño types very well, although there have been some recent improvements compared to the old generation of models (e.g., $\mathrm{Yu}$ and Kim 2010; Ham and Kug 2012; Kug et al. 2012; Kim and $\mathrm{Yu}$ 2012). The current generation of coupled models has systematically cold (dry) biases in equatorial Pacific SST (atmospheric convection) (Capotondi et al. 2006; Lin 2007; Guilyardi et al. 2009), which leads to ENSO variability to be located too far west compared with observations (Kiehl and Gent 2004). These biases are argued to limit coupled models in their ability to realistically reproduce the observed ENSO flavors (Ham and Kug 2012), as well as their teleconnections to elsewhere in the tropics (Turner et al. 2005; Annamalai et al. 2007).

Previous studies emphasized the important effect of the southward shift of central Pacific zonal winds on El Niño termination (e.g., Harrison and Vecchi 1999; Vecchi and Harrison 2003). For example, the wind anomaly shift was shown to play a dominant role during the 1997/98 El Niño demise (Vecchi 2006; Vecchi and Harrison 2006). Different features in the southward shift of wind anomalies are argued to make a contribution to the asymmetry of El Niño and La Niña duration (McGregor et al. 2013; Stuecker et al. 2013). However, results from the present study show that $\mathrm{CP}$ El Niño events display a relatively short duration compared to EP El Niño events, although no significant meridional movement of central Pacific zonal wind anomalies appears during the CP El Niño decaying phase. One possibility is related to their different SST anomaly amplitudes, since larger SST anomalies need a longer time to be damped toward the normal state. Another possibility is the existence of two leading coupled modes called the quasi-quadrennial and quasibiennial modes based on their associated frequencies (Bejarano and Jin 2008). These two modes exhibit significant differences in their periods and zonal structure, analogous to the observed EP and CP El Niño events (Ren et al. 2013). Compared to EP El Niño events, ocean-atmospheric dynamics other than the meridional shift in zonal wind anomaly structure likely play a dominant role for the CP El Niño duration. Although this work may have implications for the shorter duration of the CP El Niño, the mechanism responsible for its seasonal synchronization needs further study.

Acknowledgments. This work is supported by the National Basic Research Program "973" (2012CB417403), the Special Fund for Public Welfare Industry (Meteorology) (GYHY201506013, GYHY201406022), and Jiangsu Provincial Qinglan Project. The authors are grateful to research collaboration between University of Reading Department of Meteorology and NUIST, which has provided financial support to facilitate visits of WZ, AGT, and 
NPK to the respective institutes. We acknowledge the Met Office for data from their GA6 AMIP integrations.

\section{REFERENCES}

Adler, R. F., and Coauthors, 2003: The version-2 Global Precipitation Climatology Project (GPCP) monthly precipitation analysis (1979-present). J. Hydrometeor., 4, 1147-1167, doi:10.1175/ 1525-7541(2003)004<1147:TVGPCP > 2.0.CO;2.

An, S.-I., and F.-F. Jin, 2011: Linear solutions for the frequency and amplitude modulation of ENSO by the annual cycle. Tellus, 63A, 238-243, doi:10.1111/j.1600-0870.2010.00482.x.

Annamalai, H., K. Hamilton, and K. R. Sperber, 2007: The South Asian summer monsoon and its relationship with ENSO in the IPCC AR4 simulations. J. Climate, 20, 1071-1092, doi:10.1175/ JCLI4035.1.

Ashok, K., S. K. Behera, S. A. Rao, H. Y. Weng, and T. Yamagata, 2007: El Niño Modoki and its possible teleconnection. J. Geophys. Res., 112, C11007, doi:10.1029/2006JC003798.

Battisti, D. S., and A. C. Hirst, 1989: Interannual variability in a tropical atmosphere-ocean model: Influence of the basic state, ocean geometry, and nonlinearity. J. Atmos. Sci., 46, 1687-1712, doi:10.1175/1520-0469(1989)046<1687:IVIATA > 2.0.CO;2.

Bejarano, L., and F.-F. Jin, 2008: Coexistence of equatorial coupled modes of ENSO. J. Climate, 21, 3051-3067, doi:10.1175/ 2007JCLI1679.1.

Bjerknes, J., 1969: Atmospheric teleconnections from the equatorial Pacific. Mon. Wea. Rev., 97, 163-172, doi:10.1175/ 1520-0493(1969)097<0163:ATFTEP>2.3.CO;2.

Cai, W., and T. Cowan, 2009: La Niña Modoki impacts Australia autumn rainfall variability. Geophys. Res. Lett., 36, L12805, doi:10.1029/2009GL037885.

_, and Coauthors, 2012: More extreme swings of the South Pacific convergence zone due to greenhouse warming. Nature, 488, 365-369, doi:10.1038/nature11358.

, and Coauthors, 2014: Increasing frequency of extreme El Niño events due to greenhouse warming. Nat. Climate Change, 4, 111-116, doi:10.1038/nclimate2100.

Cane, M. A., and S. E. Zebiak, 1985: A theory for El Niño and the Southern Oscillation. Science, 228, 1085-1087, doi:10.1126/ science.228.4703.1085.

Capotondi, A., A. T. Wittenberg, and S. Masina, 2006: Spatial and temporal structure of tropical Pacific interannual variability in 20th century coupled simulations. Ocean Modell., 15, 274-298, doi:10.1016/j.ocemod.2006.02.004.

Chang, P., B. Wang, T. Li, and L. Ji, 1994: Interactions between the seasonal cycle and the Southern Oscillation: Frequency entrainment and chaos in a coupled ocean-atmosphere model. Geophys. Res. Lett., 21, 2817-2820, doi:10.1029/94GL02759.

Dee, D. P., and Coauthors, 2011: The ERA-Interim reanalysis: Configuration and performance of the data assimilation system. Quart. J. Roy. Meteor. Soc., 137, 553-597, doi:10.1002/ qj.828.

DiNezio, P. N., and C. Deser, 2014: Nonlinear controls on the persistence of La Niña. J. Climate, 27, 7335-7355, doi:10.1175/ JCLI-D-14-00033.1.

Gadgil, S., P. Joseph, and N. Joshi, 1984: Ocean-atmosphere coupling over monsoon regions. Nature, 312, 141-143, doi:10.1038/ $312141 \mathrm{a} 0$.

Graham, N., and T. Barnett, 1987: Sea surface temperature, surface wind divergence, and convection over tropical oceans. Science, 238, 657-659, doi:10.1126/science.238.4827.657.
Guilyardi, E., P. Delecluse, S. Gualdi, and A. Navarra, 2003: Mechanisms for ENSO phase change in a coupled GCM. J. Climate, 16, 1141-1158, doi:10.1175/1520-0442(2003)16<1141: MFEPCI $>2.0 . \mathrm{CO} ; 2$.

- A. Wittenberg, A. Fedorov, M. Collins, C. Wang, A. Capotondi, G. J. van Oldenborgh, and T. Stockdale, 2009: Understanding El Niño in ocean-atmosphere general circulation models: Progress and challenges. Bull. Amer. Meteor. Soc., 90, 325-340, doi:10.1175/2008BAMS2387.1.

Ham, Y.-G., and J.-S. Kug, 2012: How well do current climate models simulate two types of El Niño? Climate Dyn., 39, 383398, doi:10.1007/s00382-011-1157-3.

Harrison, D. E., 1987: Monthly mean island surface winds in the central tropical Pacific and El Niño events. Mon. Wea. Rev., 115, 3133-3145, doi:10.1175/1520-0493(1987)115<3133: MMISWI > 2.0.CO;2.

— surface temperature and wind anomalies, 1946-1993. Rev. Geophys., 36, 353-399, doi:10.1029/98RG00715.

_ and G. A. Vecchi, 1999: On the termination of El Niño. Geophys. Res. Lett., 26, 1593-1596, doi:10.1029/1999GL900316.

Hu, Z.-Z., A. Kumar, Y. Xue, and B. Jha, 2014: Why were some La Niñas followed by another La Niña? Climate Dyn., 42, 10291042, doi:10.1007/s00382-013-1917-3.

Jin, F.-F., 1997: An equatorial ocean recharge paradigm for ENSO. Part I: Conceptual model. J. Atmos. Sci., 54, 811-829, doi:10.1175/1520-0469(1997)054<0811:AEORPF $>2.0 . C O ; 2$.

, D. J. Neelin, and M. Ghil, 1994: El Niño on the devil's staircase: Annual subharmonic steps to chaos. Science, 264, 70-72, doi:10.1126/science.264.5155.70.

Kalnay, E., and Coauthors, 1996: The NCEP/NCAR 40-Year Reanalysis Project. Bull. Amer. Meteor. Soc., 77, 437-471, doi:10.1175/1520-0477(1996)077<0437:TNYRP>2.0.CO;2.

Kao, H. Y., and J. Y. Yu, 2009: Contrasting eastern-Pacific and central-Pacific types of ENSO. J. Climate, 22, 615-632, doi:10.1175/2008JCLI2309.1.

Kiehl, J. T., and P. R. Gent, 2004: The Community Climate System Model, version 2. J. Climate, 17, 3666-3682, doi:10.1175/ 1520-0442(2004)017<3666:TCCSMV>2.0.CO;2.

Kim, H.-M., P. J. Webster, and J. A. Curry, 2009: Impact of shifting patterns of Pacific Ocean warming on North Atlantic tropical cyclones. Science, 325, 77-80, doi:10.1126/science.1174062.

Kim, S. T., and J.-Y. Yu, 2012: The two types of ENSO in CMIP5 models. Geophys. Res. Lett., 39, L11704, doi:10.1029/ 2012GL052006.

Kug, J.-S., and Y.-G. Ham, 2011: Are there two types of La Niña? Geophys. Res. Lett., 38, L16704, doi:10.1029/2011GL048237.

, F.-F. Jin, and S.-I. An, 2009: Two types of El Niño events: Cold tongue El Niño and warm pool El Niño. J. Climate, 22, 1499-1515, doi:10.1175/2008JCLI2624.1.

— - Y.-G. Ham, J.-Y. Lee, and F.-F. Jin, 2012: Improved simulation of two types of El Niño in CMIP5 models. Environ. Res. Lett., 7, 034002, doi:10.1088/1748-9326/7/3/034002.

Larkin, N. K., and D. E. Harrison, 2005: On the definition of El Niño and associated seasonal average U.S. weather anomalies. Geophys. Res. Lett., 32, L13705, doi:10.1029/2005GL022738.

Lengaigne, M., J. Boulanger, C. Menkes, and H. Spencer, 2006: Influence of the seasonal cycle on the termination of El Niño events in a coupled general circulation model. J. Climate, 19, 1850-1868, doi:10.1175/JCLI3706.1.

Lin, J.-L., 2007: The double-ITCZ problem in IPCC AR4 coupled GCMs: Ocean-atmosphere feedback analysis. J. Climate, 20, 4497-4525, doi:10.1175/JCLI4272.1. 
McGregor, S., A. Timmermann, N. Schneider, M. F. Stuecker, and M. H. England, 2012: The effect of the South Pacific convergence zone on the termination of El Niño events and the meridional asymmetry of ENSO. J. Climate, 25, 5566-5586, doi:10.1175/JCLI-D-11-00332.1.

_- , N. Ramesh, P. Spence, M. H. England, M. J. McPhaden, and A. Santoso, 2013: Meridional movement of wind anomalies during ENSO events and their role in event termination. Geophys. Res. Lett., 40, 749-754, doi:10.1002/ grl.50136.

McPhaden, M. J., T. Lee, and D. McClurg, 2011: El Niño and its relationship to changing background conditions in the tropical Pacific Ocean. Geophys. Res. Lett., 38, L15709, doi:10.1029/ 2011GL048275.

Meinen, C. S., and M. J. McPhaden, 2000: Observations of warm water volume changes in the equatorial Pacific and their relationship to El Niño and La Niña. J. Climate, 13, 3551-3559, doi:10.1175/1520-0442(2000)013<3551:OOWWVC $>2.0 . C O ; 2$.

Neelin, J. D., D. S. Battisti, A. C. Hirst, F.-F. Jin, Y. Wakata, T. Yamagata, and S. E. Zebiak, 1998: ENSO theory. J. Geophys. Res., 103, 14 261-14290, doi:10.1029/97JC03424.

Ohba, M., 2013: Important factors for long-term change in ENSO transitivity. Int. J. Climatol., 33, 1495-1509, doi:10.1002/joc.3529.

_ , and H. Ueda, 2009: Role of nonlinear atmospheric response to SST on the asymmetric transition process of ENSO. J. Climate, 22, 177-192, doi:10.1175/2008JCLI2334.1.

_ D. Dohara, and H. Ueda, 2010: Simulation of asymmetric ENSO transition in WCRP CMIP3 multimodel experiments. J. Climate, 23, 6051-6067, doi:10.1175/2010JCLI3608.1.

Okumura, Y. M., and C. Deser, 2010: Asymmetry in the duration of El Niño and La Niña. J. Climate, 23, 5826-5843, doi:10.1175/ 2010JCLI3592.1.

Parks, T. W., and C. S. Burrus, 1987: Design of linear-phase finite impulse-response. Digital Filter Design, T. W. Parks and C. S Burrus, Eds., John Wiley \& Sons, 33-110.

Picaut, J., F. Masia, and Y. du Penhoat, 1997: An advective-reflective conceptual model for the oscillatory nature of the ENSO. Science, 277, 663-666, doi:10.1126/science.277.5326.663.

Rasmusson, E. M., and T. H. Carpenter, 1982: Variations in tropical sea surface temperature and surface wind fields associated with the Southern Oscillation/El Niño. Mon. Wea. Rev., 110, 354-384, doi:10.1175/1520-0493(1982)110<0354:VITSST > 2.0.CO;2.

Rayner, N. A., D. E. Parker, E. B. Horton, C. K. Folland, L. V. Alexander, D. P. Rowell, E. C. Kent, and A. Kaplan, 2003: Global analyses of sea surface temperature, sea ice, and night marine air temperature since the late nineteenth century. J. Geophys. Res., 108, 4407, doi:10.1029/2002JD002670.

Ren, H.-L., and F.-F. Jin, 2011: Niño indices for two types of ENSO. Geophys. Res. Lett., 38, L04704, doi:10.1029/ 2010 GL046031.

,,-- M. F. Stuecker, and R. Xie, 2013: ENSO regime change since the late 1970s as manifested by two types of ENSO. J. Meteor. Soc. Japan, 91, 835-842, doi:10.2151/jmsj.2013-608.

Ropelewski, C. F., and M. S. Halpert, 1987: Global and regional scale precipitation patterns associated with the El Niño/ Southern Oscillation. Mon. Wea. Rev., 115, 1606-1626, doi:10.1175/1520-0493(1987)115<1606:GARSPP > 2.0.CO;2.

— and —- 1996: Quantifying Southern Oscillationprecipitation relationships. J. Climate, 9, 1043-1059, doi:10.1175/ 1520-0442(1996)009<1043:QSOPR > 2.0.CO;2.

Schopf, P. S., and M. J. Suarez, 1988: Vacillations in a coupled ocean-atmosphere model. J. Atmos. Sci., 45, 549-566, doi:10.1175/ 1520-0469(1988)045<0549:VIACOM $>2.0 . C O ; 2$.
Spencer, H., 2004: Role of the atmosphere in seasonal phase locking of El Niño. Geophys. Res. Lett., 31, L24104, doi:10.1029/ 2004GL021619.

Stein, K., A. Timmermann, and N. Schneider, 2011: Phase synchronization of the El Niño-Southern Oscillation with the annual cycle. Phys. Rev. Lett., 107, 128501, doi:10.1103/ PhysRevLett.107.128501.

,,$--\longrightarrow$, F.-F. Jin, and M. F. Stuecker, 2014: ENSO seasonal synchronization theory. J. Climate, 27, 5285-5310, doi:10.1175/JCLI-D-13-00525.1.

Stuecker, M. F., A. Timmermann, F.-F. Jin, S. McGregor, and H.-L. Ren, 2013: A combination mode of the annual cycle and the El Niño/Southern Oscillation. Nat. Geosci., 6, 540 544, doi:10.1038/ngeo1826.

, F.-F. Jin, A. Timmermann, and S. McGregor, 2015: Combination mode dynamics of the anomalous northwest Pacific anticyclone. J. Climate, 28, 1093-1111, doi:10.1175/JCLI-D-14-00225.1.

Timmermann, A., F.-F. Jin, and J. Abshagen, 2003: A nonlinear theory for El Niño bursting. J. Atmos. Sci., 60, 152-165, doi:10.1175/ 1520-0469(2003)060<0152:ANTFEN $>2.0 . \mathrm{CO} ; 2$.

Trenberth, K. E., and J. M. Caron, 2000: The Southern Oscillation revisited: Sea level pressures, surface temperatures, and precipitation. J. Climate, 13, 4358-4365, doi:10.1175/ 1520-0442(2000)013<4358:TSORSL > 2.0.CO;2.

Turner, A. G., P. M. Inness, and J. M. Slingo, 2005: The role of the basic state in the ENSO-monsoon relationship and implications for predictability. Quart. J. Roy. Meteor. Soc., 131, 781804, doi:10.1256/qj.04.70.

Tziperman, E., L. Stone, M. A. Cane, and H. Jarosh, 1994: El Niño chaos: Overlapping of resonances between the seasonal cycle and the Pacific Ocean-atmosphere oscillator. Science, 264, 7274, doi:10.1126/science.264.5155.72.

, M. A. Cane, S. E. Zebiak, Y. Xue, and B. Blumenthal, 1998: Locking of El Niño's peak time to the end of the calendar year in the delayed oscillator picture of ENSO. J. Climate, 11, 2191-2199, doi:10.1175/1520-0442(1998)011<2191:LOENOS>2.0.CO;2.

Uppala, S. M., and Coauthors, 2005: The ERA-40 Re-Analysis. Quart. J. Roy. Meteor. Soc., 131, 2961-3012, doi:10.1256/ qj.04.176.

van Loon, H., and R. A. Madden, 1981: The Southern Oscillation. Part I: Global associations with pressure and temperature in northern winter. Mon. Wea. Rev., 109,1150-1162, doi:10.1175/ 1520-0493(1981)109<1150:TSOPIG > 2.0.CO;2.

Vecchi, G., 2006: The termination of the 1997-98 El Niño. Part II: Mechanisms of atmospheric change. J. Climate, 19, 2647-2664, doi:10.1175/JCLI3780.1.

— and D. E. Harrison, 2003: On the termination of the 2002-03 El Niño event. Geophys. Res. Lett., 30, 1964, doi:10.1029/ 2003GL017564.

— , and - 2006: The termination of the 1997-98 El Niño. Part I: Mechanisms of oceanic change. J. Climate, 19, 2633-2646, doi:10.1175/JCLI3776.1

Wallace, J. M., E. M. Rasmusson, T. P. Mitchell, V. E. Kousky, E. S. Sarachik, and H. Von Storch, 1998: On the structure and evolution of ENSO-related climate variability in the tropical Pacific: Lessons from TOGA. J. Geophys. Res., 103, 1424114 259, doi:10.1029/97JC02905.

Wang, B., A. Barcilon, and Z. Fang, 1999: Stochastic dynamics of El Niño-Southern Oscillation. J. Atmos. Sci., 56, 5-23, doi:10.1175/1520-0469(1999)056<0005:SDOENO > 2.0.CO;2.

, R. Wu, and X. Fu, 2000: Pacific-East Asian teleconnection: How does ENSO affect East Asian climate? J. Climate, 13, 1517-1536, doi:10.1175/1520-0442(2000)013<1517:PEATHD>2.0.CO;2. 
__ B. Xiang, and J.-Y. Lee, 2013: Subtropical high predictability establishes a promising way for monsoon and tropical storm predictions. Proc. Natl. Acad. Sci. USA, 110, 2718-2722, doi:10.1073/pnas.1214626110.

Wang, C., and X. Wang, 2013: Classifying El Niño Modoki I and II by different impacts on rainfall in southern China and typhoon tracks. J. Climate, 26, 1322-1338, doi:10.1175/JCLI-D-12-00107.1.

Weisberg, R. H., and C. Wang, 1997: A western Pacific oscillator paradigm for the El Niño-Southern Oscillation. Geophys. Res. Lett., 24, 779-782, doi:10.1029/97GL00689.

Wyrtki, K., 1975: El Niño-The dynamic response of the equatorial Pacific Ocean to atmospheric forcing. J. Phys. Oceanogr., 5, 572584, doi:10.1175/1520-0485(1975)005<0572:ENTDRO > 2.0.CO;2.

Yeh, S.-W., J.-S. Kug, B. Dewitte, M.-H. Kwon, B. P. Kirtman, and F.-F. Jin, 2009: El Niño in a changing climate. Nature, 461, 511-514, doi:10.1038/nature08316.

Yu, J.-Y., and S. T. Kim, 2010: Identification of central-Pacific and eastern-Pacific types of ENSO in CMIP3 models. Geophys. Res. Lett., 37, L15705, doi:10.1029/2010GL044082.

Zhang, W., and F.-F. Jin, 2012: Improvements in the CMIP5 simulations of ENSO-SSTA meridional width. Geophys. Res. Lett., 39, L23704, doi:10.1029/2012GL053588.
— J. Li, and F.-F. Jin, 2009: Spatial and temporal features of ENSO meridional scales. Geophys. Res. Lett., 36, L15605, doi:10.1029/2009GL038672.

_ - F.-F. Jin, J. Li, and H.-L. Ren, 2011: Contrasting impacts of two-type El Niño over the western North Pacific during boreal autumn. J. Meteor. Soc. Japan, 89, 563-569, doi:10.2151/ jmsj.2011-510.

_, J. X. Zhao, and J. Li, 2013a: On the bias in simulated ENSO SSTA meridional widths of CMIP3 models. J. Climate, 26, 3173-3186, doi:10.1175/JCLI-D-12-00347.1.

, — - - L L. Qi, and H.-L. Ren, 2013b: The possible influence of a nonconventional El Niño on the severe autumn drought of 2009 in southwest China. J. Climate, 26, 8392-8405, doi:10.1175/JCLI-D-12-00851.1.

$\ldots, \ldots$, and A. G. Turner, 2014: Increasing autumn drought over southern China associated with ENSO regime shift. Geophys. Res. Lett., 41, 4020-4026, doi:10.1002/ 2014GL060130.

—, L. Wang, B. Xiang, L. Qi, and J. He, 2015: Impacts of two types of La Niña on the NAO during boreal winter. Climate Dyn., 44, 1351-1366, doi:10.1007/ s00382-014-2155-z. 